\title{
Antibacterial Resistance in African Catfish Aquaculture: a Review
}

\author{
Madubuike U. ANYANWU*, Kennedy F. CHAH \\ University of Nigeria, Faculty of Veterinary Medicine, Microbiology Unit, \\ Department of Veterinary Pathology and Microbiology, Veterinary Antimicrobial Resistance Research Group, Nsukka, Enugu State, Nigeria; \\ madubuike.anyanwu@unn.edu.ng(*orrespondingauthor);kennedy.chah@unn.edu.ng
}

\begin{abstract}
Antibacterial resistance (AR) is currently one of the greatest threats to mankind as it constitutes health crisis. Extensive use of antibacterial agents in human and veterinary medicine, and farm crops have resulted in emergence of antibacterial-resistant organisms in different environmental settings including aquaculture. Antibacterial resistance in aquaculture is a serious global concern because antibacterial resistance genes (ARGs) can be transferred easily from aquaculture setting to other ecosystems and the food chain. African catfish (ACF) aquaculture has increased at a phenomenal rate through a continuous process of intensification, expansion and diversification. Risk of bacterial diseases has also increased and consequently there is increased use of antibacterial agents for treatment. Antibacterial resistance in ACF aquaculture has huge impact on the food chain and thus represents risk to public and animal health. In "one health" approach of curbing AR, knowledge of the sources, mechanisms and magnitude of AR in ACF aquaculture and its potential impact on the food chain is important in designing and prioritizing monitoring programs that may generate data that would be relevant for performing quantitative risk assessments, implementation of antibacterial stewardship plans, and developing effective treatment strategies for the control of ACF disease and reducing risk to public health. This review provides insight on the sources, mechanisms, prevalence and impact of antibacterial resistance in ACF aquaculture environment, a setting where the impact of AR is neglected or underestimated.
\end{abstract}

Keywords: African catfish, aquaculture, antibacterial resistance, piscine

\section{Introduction}

Aquaculture is the fastest growing food industry in the world, providing approximately $50 \%$ of animal protein required by individuals and employment opportunities for the growing population (FAO/OIE/WHO, 2006; Rodgers and Furones, 2009; Bostock et al., 2010; Khairnar et al., 2013). Intensification of fish results in explosion of bacterial organisms in aquaculture and the need for antibacterial agents to control and/or treat bacterial infections (Ishida et al., 2010; Defoirdt et al., 2011; Jiang et al., 2013). African catfish (ACF), Clarias gariepinus, also called African sharptoothed catfish, African magur, Barbel or Skerptand barber is freshwater finfish which originated in Africa and has been introduced into the Middleeast and Eastern Europe (DeMoor and Bruton, 1988; Ibrahem and Mesahly, 2010; Hamid et al., 2012; Anyanwu et al., 2015). The ACF is the most widely farmed freshwater finfish in Africa. African catfish aquaculture has helped in the provision of animal protein and employment in low and medium income food deficient countries (LMIFDCs) especially African countries, where many obtain $<15$ gm daily animal protein intake (DAPI) far less than $35 \mathrm{gm}$ DAPI recommended by the WHO/FAO (FAO, 2000; FAO/OIE/WHO, 2006; Ekine et al., 2012). Attributes of ACF that encourage its increased farming include: adaptability to tropical environment, suitability for monoculture and polyculture with other freshwater fish species, tolerance to high stocking density, ability to withstand handling stress, disease resistance, high fecundity, high weight gain, palatability and nutritional quality, low production cost and less bias when compared with other animal protein sources (Haylor, 1991; Musefiu et al., 2011; Kumar et al., 2012; Anyanwu et al., 2015). ACF aquaculture has increased at a phenomenal rate in the last decennium (Olatoye and Basiru, 2013; Anyanwu et al., 2014; Ibrahem et al., 2015). The rapid increase in ACF farming is due to the decline in wild/feral fish population as a consequence of overfishing, drying up of natural water bodies due to climate change, increasing population, and pollution of water bodies by oil spills and other anthropogenic contaminants (FAO, 2008; Clausen and York, 2008; Cruz et al., 2012; Ibrahem, 2015).

Majority of the countries where ACF is farmed are developing/less industrialized nations (i.e. LMIFDCs) where the use of antibacterial agents is not regulated, a factor that may facilitate the development of antibacterial resistance (AR) (FAO/OIE/WHO, 2006; Cabello et al., 2013; Laxminarayan et al., 2013). This sort of practice contrasts that in finfish aquaculture in developed countries, where few regulated antibacterial agents are allowed for use (Armstrong et al., 2005; FAO/OIE/WHO, 2006; Rodgers and Furonone, 2009; Cabello et al., 2013). The warm humid tropical climate of these countries also facilitates the development and spread of AR (Okeke and Edelman, 2001). Many antibacterial drugs in the same class as those used in human medicine are used in finfish aquaculture (FAO/OIE/WHO, 2006; Laxminarayan et al., 
2013; Canica et al., 2015). The major concern surrounding the use of antibacterial agents in aquaculture is considered to be the potential to favour the development of a reservoir of antibacterial resistance genes (ARGs) that may be eventually transferred to clinically relevant bacteria, especially via the food chain (FAO/OIE/WHO, 2006; Miranda et al., 2013). Mobile genetic elements (MGE) (mobilomes) of bacterial genomes such as plasmids, transposons, insertion sequences, genomic islands and phages) facilitate the spread of ARGs by horizontal transfer in aquaculture environments and subsequently by lateral transfer to other environmental settings (Canica et al., 2015). Non-mobile genetic elements such as integrons (especially the class 1 integrons) also carry gene cassettes, transposons and plasmids containing ARGs (Jacobs and Chenia, 2007; Patridge et al., 2009; Ndi and Barton, 2011). The global climatic change may worsen the problem of AR as it may affect the emergence and dynamics of new and existing pathogens and consequently the use of antibacterial agents and prevalence of AR (Tirado et al., 2010; Miranda et al., 2013). Antibacterial-resistant organisms (AROs)/ARGs emanating from ACF aquaculture can spread to other parts of the world through international travel and importation/exportation of food, thereby changing the dynamics of AR globally (Okeke and Edelman, 2001; Canica et al., 2015). Indeed, different types/classes of antibacterial drugs critical to human medicine are used in aquaculture, a situation that may have facilitated AR in ACF aquaculture (Heuer et al., 2009; Defoirdt et al., 2011; Cabello et al., 2013).

The "one health" approach recently proposed by the WHO in monitoring and devising strategy for curbing AR in any ecological niche requires that the sources, route of spread and impact on the food chain be taken into consideration (WHO, 2014). Thus, knowledge of the molecular and genetic mechanisms of phenotypic AR in ACF aquaculture environment, and the impact on the food chain is important to design and prioritize monitoring programs that may generate data that would be relevant for performing quantitative risk assessments, implementation of antibacterial stewardship plans, and developing sound treatment strategies for the control of ACF disease and reducing the risk to public health. This review provides information on the sources, molecular and possible genomic mechanisms, and prevalence of phenotypic resistance to $\beta$-lactam, aminoglycoside, quinolone, tetracycline, glycopeptide, nitrofuran, potentiated sulphonamide and phenicol that has been reported to occur in ACF aquaculture environments, and the impact of the resistance on the food chain and public health.

\section{Sources of antibacterial resistance in African catfish aquaculture environment}

Although $\mathrm{AR}$ is a natural phenomenon for adaptation (i.e., innate resistance) (Moellering and Krogstad. 1979; Livermore, 2003; Tenover, 2006), bacterial organisms develop acquired resistance by mutation of genes and/or acquisition of ARGs through horizontal transfer (transformation, conjugation and transduction) following exposure to sub-therapeutic/low doses of antibacterial agents (Wegener et al., 1999; Okeke and Edelman, 2001; Livermore, 2003; Waters et al., 2011; VazMoreira et al., 2014). Exposure of bacteria to sub-therapeutic doses of antibacterial agents causes use (exposure) selection pressure, acquisition of ARGs and exhibition of resistance mechanisms by the organisms so as to counter or thwart the effects of antibacterial agents in the environment (Tenover, 2006; Laxminarayan et al., 2013). The use of substandard/counterfeit drugs (i.e. low concentrations) in ACF aquaculture as often the case in developing countries facilitates the development of AR (Okeke and Edelman, 2001; Laxminarayan et al., 2013). Low concentrations of drugs results in selection for resistance to other drug classes while target strains remain susceptible to the drug; this occurs because of random mutagenesis and such resistance is irreversible (Cogliani et al., 2011).

Several factors contribute towards the emergence of $A R$ in an ACF aquaculture environment. The major trigger of $A R$ in ACF aquaculture is the routine use of antibacterial agents in prevention of bacterial infections (prophylaxis), treatment of infected fish both poorly and adequately diagnosed (therapeutics) and treatment of infected fish in a population of healthy fish (metaphylaxis) (Cabello, 2006; Smith, 2008; Heuer et al., 2009; Vaz-Moreira et al., 2014). From its inception the ACF aquaculture industry, like any other finfish aquaculture, has used antibacterial agents as means to mitigate bacterial infections (Armstrong et al., 2005; Cabello et al., 2013). Lowered host defenses associated with culture at high density with suboptimal hygiene in enclosures in close proximity led to heavy reliance on antibacterial agents (Cabello et al., 2013). The absences of biosecurity and vaccination programs, which are either not effectively applied or available, coupled with the ban of malachite green in aquaculture may also have exacerbated the use of antibacterial agents in ACF aquaculture (Armstrong et al., 2005; Jiang et al., 2013; Anyanwu et al., 2014). Antibacterial agents are administered to individual fish either orally with feed or water, injected directly intramuscularly, or immersed in drug solution by dipping for a short period of time or bathing for a long duration (Komar et al., 2004; Smith, 2008; Rodgers and Furonones, 2009). The immersion method is also used for treating several numbers of fish (Komar et al., 2004; FAO/OIE/WHO, 2006; Aly et al., 2014). However, these methods are rarely used because they are laborious, timeconsuming (because fish are brought out of rearing water and returned thereafter) and costly than administering medicated feed in rearing water which is easier, more convenient, and timesaving (Harper, 2002; Jacobs and Chenia, 2007; Smith, 2008; Cabello et al., 2013). Bacterial organisms colonizing treated fish become exposed to the antibacterial drug, and may develop resistance especially if the therapeutic concentration/dose of the drug is not attained (Okeke and Edelman, 2001).

Although feed medication in fish-rearing water (i.e. metaphylactic) is the most convenient and widely practiced method of drug administration (Smith, 2008; Vaz-Moreira et al., 2014), it induces AR in ACF aquaculture more than the other methods (Armstrong et al., 2005; Cabello, 2006). Infected fish often have a reduced appetite, thus the administered drugs may not be taken by the fish (Armstrong et al., 2005; Smith, 2008; Cabello et al., 2013). Adjustment of feeding rates to minimize loss of uneaten food may not improve absorption of antibacterial drugs (Armstrong et al., 2005; Smith, 2008). Uningested drug associated with the feed and approximately $75-80 \%$ of ingested drug which pass into the environment in unabsorbed form in faeces or after absorption, in secreted forms in urine and other secretions, deposits in the pond sediment by gravity (Armstrong 
et al., 2005; Burridge et al., 2010; Cabello et al., 2013). This results in increased concentrations of the antibacterial agent in the aquaculture (Alderman et al., 1994; Weston, 1996; Armstrong et al., 2005). Thus, bacterial population in the ACF aquaculture continually becomes exposed to the deposited drug, consequently resulting in development of $\mathrm{AR}$ mechanisms (Armstrong et al., 2005). However, the extent/length of exposure of organisms by sediment antibacterial (i.e. time antibacterial activity of drug remains) is dependent on the initial concentration of the agent (i.e. proportional to the amount of the drug administered), its chemical structure and half life, environmental chemical and physical variables such as sediment characteristics, temperature, light and $\mathrm{pH}$ (Boxall et al., 2004; Kummerer, 2009; Cabello et al., 2013). Introduction of large amounts of antibacterial agents into the aquatic environment results in emergence of significant numbers of multiple-resistant bacteria since ARGs enhances fitness for growth in sediments containing antibacterial agents (Cabello et al., 2013).

Antibacterial-resistant organisms colonizing aquaculture workers can enter the aquaculture when contact is made with the fish-rearing water (Jacobs and Chenia, 2007). The workers can also contaminate the fish feed. Movement of AROs/ARGs from the workers to ACF aquaculture can be easy due to poor sanitation (antibacterial agents often used in replacement of poor hygiene) and infection control practices often observed in developing countries (Okeke and Edelman, 2001).

Another source of AR in ACF aquaculture is the fish feed. ACF is fed with variety of materials including commercially manufactured feed, dead animals, insects, animal manures, slaughterhouse wastes (e.g., intestines, meat) and kitchen wastes (Kumar et al., 2012; Omojowo and Omojasola, 2013). Antibacterial agents are usually incorporated into the commercial fish feeds at sub-therapeutic doses for prophylaxis and/or growth-promotion (Castanon, 2007; Rodgers and Furonones, 2009). This also exposes the bacterial population in the aquaculture to non-lethal concentration of the drugs, consequently AR may develop. The feed itself may be contaminated with AROs by humans during the manufacturing, transportation or fish feeding process (FAO/OIE/WHO, 2006). The AROs then disseminates ARGs by horizontal transfer to others in the aquaculture.
Feeding of fish with invertebrates (such as insects, maggots, earthworms), dead animals, slaughterhouse wastes and animal manure which also promotes algal growth, are often considered economical by ACF farmers (Kumar et al., 2012; Omojowo and Omojasola, 2013). An often neglected source of AR in ACF aquaculture is invertebrate vectors (e.g. insect vectors such as houseflies, and soil dwellers e.g., earthworms) which are potential carriers of AROs (Devi and Murray, 1991; Blaak et al., 2014). Insects are often available in ACF aquaculture environment because the humid tropical climate in most of the countries rearing this species of finfish favours their development (Okeke and Edelman, 2001). These invertebrates are vectors of AROs/ARGs which colonize them in their ecological niches (Zurek and Ghosh, 2014). In some ACF aquaculture systems, light source placed over the rearing water attract these insects which are consumed by the fish. Maggots harvested from decomposing animal manure are also used in feeding ACF; these potentially carry AROs/ARGs into ACF aquaculture. Unfortunately, slaughterhouse wastes and animal manure used in feeding ACF are reservoirs of AROs/ARGs (Sayah et al., 2005; Omojowo and Omojasola, 2013). Dead animals used in feeding ACF are also potential sources of AROs, their death often resulting from poorly diagnosed, misdiagnosed or inappropriately-treated bacterial infections.

Livestock manure often loaded with myriads of AROs is used to feed ACF and for fertilization of rearing water to promote the growth of photosynthetic organisms (phytoplanktons, algae) consumed by the fish (Peteersen et al., 2002; Sayah et al., 2005; Omojowo and Omojasola, 2013). Integrated African catfish farming (IACF) combines livestock production with ACF farming (Peteersen et al., 2002; Omojowo and Omojasola, 2013). In this IACF, animal manure shed directly into the rearing water is consumed by fish (Little and Edwards, 1999; Petersen et al., 2002; Aly et al., 2014). Although the IACF system produces high yields with low input, since the fish receive limited, if any, supplementary feed, the livestock on the integrated farms (usually chickens and pigs), is reared intensively with antibacterial agents for growth-promotion, prophylaxis and therapeutics (Petersen et al., 2002). Thus, within IACF farming systems, antibacterial drugs, their residues, and AROs enter the aquaculture through livestock manure (Petersen

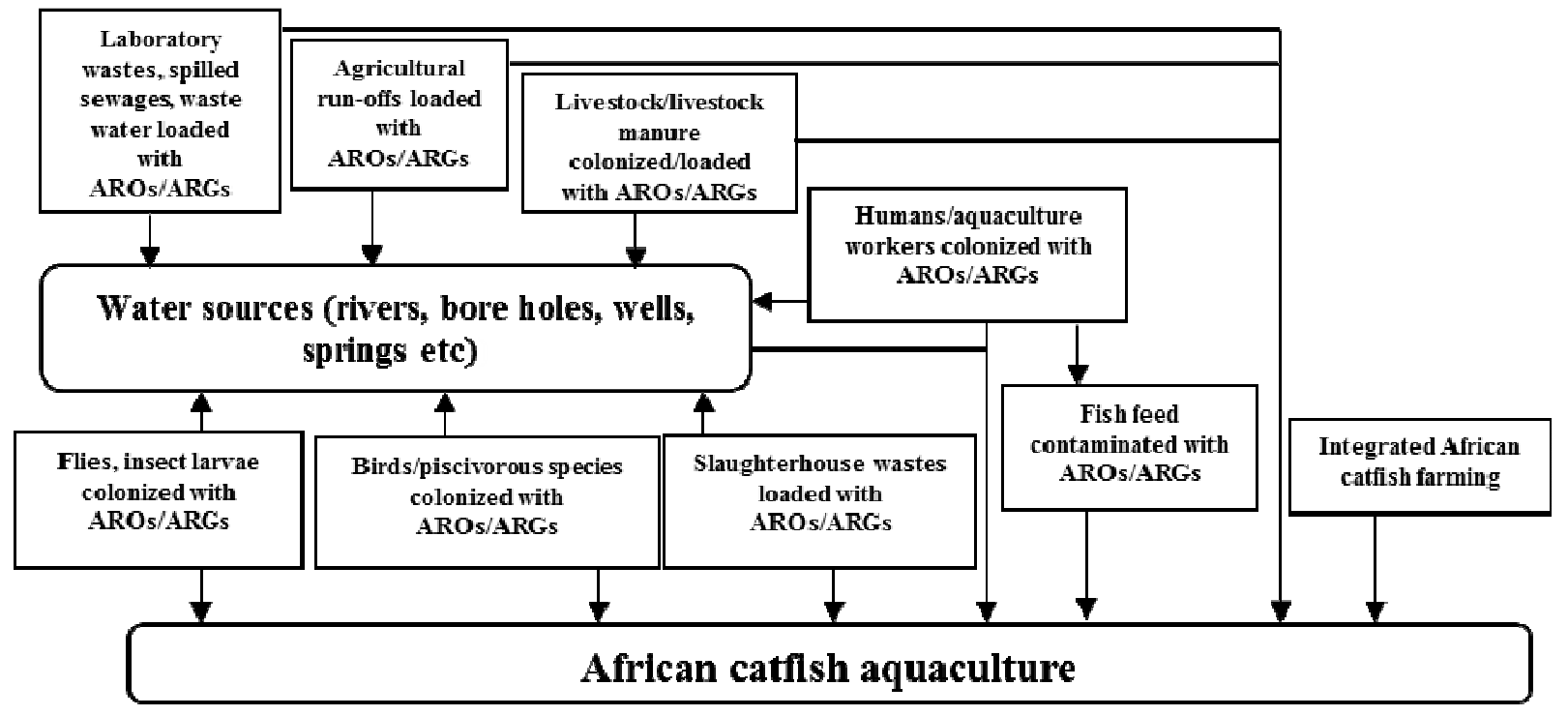

Fig. 1. Sources of antibacterial resistant organisms (AROs)/antibacterial resistance genes (ARGs) in African catfish aquaculture 
et al., 2002; Aly et al., 2014). The AROs in the manure potentially transfer ARGs to bacterial population in the aquaculture (Petersen et al., 2002; Omojowo and Omojasola, 2013). Therefore, supposedly economical feeding strategies become crucial source of AR in ACF aquaculture environments.

Non-selective micro-feeders habouring AROs and ARGshabouring bacteria in rearing water, particularly water contaminated with materials from anthropogenic activities (as often the case in developing countries), are very important sources of AR in ACF aquaculture (FAO/OIE/WHO, 2006). Over-flying and piscivorous birds also serve as sources of AR in ACF aquaculture; these birds are reservoirs of AROs/ARGs (Shobrak and Abor-Amey, 2014). The use of antibacterial agents as biocides and additives in crops facilitates AR in bacterial organisms colonizing plants (Canica et al., 2015). Run-offs may carry AROs from the crops and those from anthropogenic activities (e.g., laboratories, animal manure used for fertilizing crops, spilled sewages, waste water, etc) into natural water bodies (potential sources of water for ACF aquaculture) and aquaculture (Rhodes et al., 2000; Heuer $e t$ al., 2011; Nikiema $e t$ al., 2013; Canica et al., 2015). This is an important source of AR in earthen ACF ponds with low surface barriers. By horizontal transfer, bacterial population in aquaculture acquire ARGs from diverse sources (Fig. 1) and consequently develop resistance to different antibacterial agents.

\section{Antibacterial resistance among isolates from African catfish aquaculture}

\section{Quinolone and fluoroquinolone resistance}

Quinolones (e.g., nalidixic acid) and fluroquinolones (quinolone with fluorine atoms attached; e.g. ciprofloxacin, enrofloxacin, ofloxacin etc) are bactericidal agents which kill bacteria by inhibiting DNA synthesis, specifically DNA supercoiling and stability (Khodursky and Cozzarelli, 1998; Hooper, 2001; Miranda et al., 2013). Quinolones target bacterial enzymes, DNA gyrase and topoisomerase IV (Hooper, 2001; Miranda et al., 2013). Both DNA gyrase and topoisomerase IV are tetrameric enzymes encoded by the $g y r A$ and $g y r B$ genes, and $\operatorname{par} C$ and $\operatorname{par} E$ genes, respectively (Hooper, 2001; Rodhkum et al., 2002; Miranda et al., 2013). While the main activity of DNA gyrase is to catalyze the negative supercoiling of bacterial DNA, topoisomerase IV decatenate and relax the activity of daughter replicons following DNA replication (Hawkey, 2003; Miranda et al., 2013). Chromosomal mutation of the gyrase and topoisomerases genes $(g y r A, \operatorname{gyr} B$, parC, parE), mutations that reduce drug accumulation by decreasing uptake or increasing efflux, and at least three plasmidmediated/encoded quinolone resistance (PMQR) mechanisms such as rQnr proteins, AAC(6)-Ib-cr aminoglycoside acetyltransferases, and QepA and OqxAB efflux pumps, have been reported to be mechanisms of acquired quinolone resistance in bacteria, including isolates from finfish aquaculture (Drlica, and Zhao, 1997; Tran and Jacoby, 2002; Ruiz, 2003; Buschmann et al., 2012; Miranda et al., 2013). It has been suggested that hydrophilic fuoroquinolones (such as enrofloxacin) can be extruded by plasmid-encoded active efflux pumps QepA and OqxAB (Li, 2005; Poirel et al., 2008, 2012; Miranda et al., 2013). Topoisomearse protection genes qnr $A$, qnrB, $q n r D$ and $q n r S$ have been reported in isolates from several finfish farms (Ishida et al., 2010; Buschmann et al., 2012; Takjbash et al., 2015). Water-borne Vibrionaceae are known to habour several $q n r$ genes, thus they are speculated to be natural reservoirs of Qnr-like quionolone resistance determinants (Cattoir and Nordmann, 2009; Miranda et al., 2013). The putative enzymatic inactivation genes aac (69)-Ib-cr, aac (6)-Ib-cr have also been detected in bacterial isolates from finfish aquaculture (Buschmann $e t$ al., 2012; Jiang et al., 2012). Some authors suggested that QnrS determinants may act as reservoirs of $q n r$ gene similar to the tet genes (Rhodes et al., 2000; Schmidt et al., 2001; Miranda et al., 2013). Most importantly, qnrplasmids are often associated with intergrons and they carry multiple resistance determinants, providing resistance to several classes of antimicrobials, including $\beta$ lactams and aminoglycosides (Li, 2005; Miranda et al., 2013).

In ACF aquaculture, resistance of bacterial isolates to quinolones and fluoroquinolones have been reported. Kumar et al. (2012) reported that Flavobacterium columnare isolates from ACF in India, exhibited resistance to nalidixic acid (100\%) and ofloxacin (100\%). Efuntoye et al. (2012) reported $9.1 \%$ resistance to ciprofloxacin among Pseudomonas isolates from ACF in Nigeria. The study also reported $5.9 \%, 63.6 \%, 14.3 \%$ and $6.7 \%$ resistance to nalidixic acid among Escherichia coli, Pseudomonas, Salmonella and Staphylococcus isolates, respectively. Another Nigerian study reported 100\% resistance to nalidixic acid among Staphylococcus and Streptococcus isolates from ACF (Adedeji et al., 2011). The study also reported $37.5 \%$ resistance to ofloxacin among the Streptococcus and Staphyloccocus isolates, and 75\% ciprofloxacin resistance and 100\% norfloxacin resistance among the Salmonella isolates. Anyanwu et al. (2014) reported $11 \%$ resistance to enrofloxacin among Aeromonas isolates from ACF in Nigeria. In Bangladesh, Nahiduzzaman et al. (2000) reported 20\% resistance to oxolinic acid among Aeromonas and Pseudomonas isolates from rearing water and ACF. In Malaysia, Wei et al. (2011) reported $42.9 \%$ resistance to nalidixic acid among 7 Edwardsiella tarda isolates from polycultured ACF. It is evident from these studies that quinolone/fluoroquinolone resistance has emerged in bacterial agents from ACF.

\section{Aminoglycoside resistance}

Aminoglycosides are bactericidal agents which kill bacteria by binding to the $30 \mathrm{~S}$ ribosomal subunit for streptomycin (Mingeot-Leclercq et al., 1999; Carter et al., 2000) and to both $50 \mathrm{~S}$ and a site on the $30 \mathrm{~S}$ subunit different from that of streptomycin for kanamycin and neomycin (Greenwood, 2000). Mechanisms of bacterial resistance to aminoglycosides is by reduction in drug uptake/decreased permeability, alteration of ribosomal binding sites, enzymatic drug modifications (the most common mechanism), and efflux pump (Aires and 
Nikaido, 2005; Abatcha et al., 2014). Bacterial aminoglycoside modifying enzymes include: acetyltransferases, adenyltransferases and phosphotransferases encoded by the genes aac, aad and aph, respectively (Szczepanowski et al., 2009; Abatcha et al., 2014). Gene cassettes containing both $a p h$ and aac genes, have been reported in bacterial isolates from finfish farm environment (Su et al., 2011). Aminoglycoside determinants such as aac(3)-IIa in E. coli (Tajbakhsh et al., 2015), aad associated with class 1 intergrons in Aeromonas (Ndi and Barton, 2011), E. coli (Ryu et al., 2012) and Pseudomonas (Ndi and Barton, 2012) have been reported in isolates from aquaculture. The genes $\operatorname{str} A(a p h(3)-I b)$ and $\operatorname{str} B(a p h(6)-I d)$ encoding aminoglycoside 3'-phosphotransferase and aminoglycoside 6-phosphotransferase, respectively (Szczepano-wski $e t$ al., 2009), have also been detected in isolates from finfish aquaculture (Shah et al., 2012; Pereira et al., 2013). The AAC(6)-Ib-cr aminoglycoside transferase determinant which mediates resistance to quinolones and aminoglycoside has been reported in finfish aquaculture (Ishida et al., 2010; Miranda $e t$ al., 2013). Co-occurrence of aminoglycoside genes with other determinants associated with class 1 integrons (e.g., tetA/florA/sul1-sul2/int1-dfrA12-aadA) (Ryu et al., 2012) and class 2 integrons (e.g., dfrA1-sat-aadAI) (Pereira et al., 2013) have been reported in finfish aquaculture.

Varying resistance rates to different aminoglycosides have been reported among bacterial isolates from ACF aquaculture. Flavobacterium columnare isolates from ACF in India exhibited $100 \%$ resistance to gentamicin, amikacin, oleandamycin and tobramycin (Kumar et al., 2012). In Malaysia, Laith and Najiah (2013) reported $9.09 \%$ resistance to novobiocin among $A$. hydrophila isolates from ACF. In Nigeria, $11.8 \%, 9.1 \%$ and $6.7 \%$ resistance to novobiocin among E. coli, Pseudomonas and Staphylococcus isolates from ACF, respectively, were reported by Efuntoye et al. (2012). The study also reported $7.6 \%, 18.2 \%$ and $40 \%$ resistance to gentamicin among the respective isolates, and $71.4 \%$ among Salmonella isolates. The rates of streptomycin resistance reported by the study were $29.4 \%, 36.4 \%, 42.9 \%$ and $46.7 \%$ among the respective isolates. Anyanwu et al. (2014) reported 66\% resistance to streptomycin among Aeromonas isolates from ACF in some states in Southeastern Nigeria. A different Nigerian study reported $100 \%$ resistance to gentamicin among Streptococcus isolates from ACF (Adedeji et al., 2011). A Bangladeshi study reported $10 \%$ and $40 \%$ resistance to streptomycin among Aeromonas and Pseudomonas isolates from rearing water and ACF hybrid (Nahiduzzaman et al., 2000). In Malaysia, Wei et al. (2011) reported 14.3\% resistance to kanamycin among 7 E. tarda isolates from ACF.

\section{Tetracycline resistance}

Tetracyclines are broad-spectrum bacteriostatic antibiotics that interfere with protein synthesis by reversibly binding to the $30 \mathrm{~S}$ and $70 \mathrm{~S}$ ribosomal subunit, thereby blocking the binding of the aminoacyl tRNA to the mRNA/ribosome complex (Roberts, 1996; Armstrong et al., 2005; Miranda et al., 2013). Mechanisms of bacterial resistance to tetracycline include active efflux, ribosomal protection, ribosomal RNA mutations, and tetracycline inactivation (Speer and Salyers, 1989; Burdett,
1991; Speer et al., 1992; Taylor and Chau, 1996; Miranda et al., 2013). The commonest tetracycline resistance mechanisms in fish farm-associated bacteria include one or more of the Tet family of proton-dependent efflux pumps and/or via ribosomal protection by cytoplasmic proteins found widely in Gramnegative bacteria (Roberts, 2005; Roberts et al., 2012; Miranda et al., 2013).

Several tetracycline determinants including $\operatorname{tet} A$, tet $B$, tet $E$, tet $H$, tet $L$, tet 34, tet $C$, tet $D$, tet $35 \operatorname{tet} G$, $\operatorname{tet} M$, tet $O$, tet $Q$, tet $S$, and $t e t W$ have been detected in bacterial isolates from many finfish farms (Furishita et al., 2003; Ishida et al., 2010; Miranda et al., 2013). The prevalence of these genes in aquaculture habitats vary (Nawaz et al., 2009; Miranda et al., 2013). The spread of tet genes is often facilitated by their location on mobile genetic elements, such as plasmids and transposons, factors that are known to play a significant role in global dissemination of tet genes (Chopra and Roberts, 2001; Sørum et al., 2003; Miranda et al., 2013). The tet genes have been associated with both mobile and non-mobile plasmids (Miranda et al., 2013). Edwardsiella isolates from a fish farm in Korea carried tet $\mathrm{A}$ and $t e t \mathrm{D}$ on mobile plasmids while tet $\mathrm{B}$ and tet $\mathrm{G}$ were associated with non-mobile plasmids (Juan $e t$ al., 2004; Miranda et al., 2013). Co-occurrence of tet genes with other resistance genes (usually harboured by class 1 intergron) in finfish aquaculture have been reported (Jacobs and Chenia, 2007; Su et al., 2011; Miranda et al., 2013). The frequent occurrence of the tet gene in finfish aquaculture reflects the fact that it has being in use for long, being the first antibacterial agent to be approved for use in aquaculture (USFDA, 2009).

Resistance to tetracycline has severally been reported among different bacterial isolates from ACF aquaculture. Efuntoye et al. (2012) reported $82.4 \%, 72.7 \%, 28.6 \%$ and $40 \%$ resistance to tetracycline among E. coli, Pseudomonas, Salmonella and Staphylococcus isolates from ACF in Nigeria. A similar study in Nigeria reported $37.5 \%$ resistance to tetracycline among Staphylococcus isolates, and 100\% among Salmonella and Streptococcus isolates, respectively, from ACF (Adedeji et al., 2011). Another Nigerian study reported 89\% resistance to tetracycline among Aeromonas isolates from ACF (Anyanwu et al., 2014). Nahiduzzaman et al. (2000) reported $70 \%$ and $80 \%$ resistance to oxytetracycline among Aeromonas and Pseudomonas isolates from rearing water and ACF hybrid in Bangladesh. Tetracycline resistance of $42.9 \%$ was reported by Wei et al. (2011) among 7 E. tarda isolates from ACF in Malaysia. Apart from the fact that tetracycline (particularly oxytetracycline) is frequently used in ACF aquaculture because of its broad-spectrum effect (Olatoye and Basiru, 2013; Anyanwu et al., 2014), the source of tetracycline resistance in ACF aquaculture environment is most probably from livestock manure, dead animals and aquaculture workers because the drug has been tremendously abused in veterinary and human medicine especially in developing countries (Hart and Kariku, 1998; Roberts, 2003).

\section{Macrolide and lincosamide resistance}

Macrolides and lincosamides are bacteriostatic agents which inhibit bacterial protein synthesis by binding to the $50 \mathrm{~S}$ ribosomal subunit (Canu and Lerclerq, 2009). Lincosamides can 
also elicit bactericidal effect depending on the concentration and sensitivity of the targeted organism (Tenson et al., 2003). Although macrolides and lincosamides are chemically/structurally distinct, they share a similar mode of action (Isnard et al., 2013). Their activity is limited mainly to Gram-positives and bacilli, Gram-negative cocci, and intracellular bacteria such as Chlamydia and Rickettsia (Lerclerq, 2002). Mechanisms of bacterial resistance to macrolide and lincosamide include: target site modification by methylation or mutation that prevents the binding of the drug to its ribosomal target, efflux of the drug, and drug inactivation (Lerclerq, 2002; Hot et al., 2014). Mutations at several sites of the ribosome allosterically prevent macrolide binding and a common alteration is dimethylation of one nucleotide (a single adenine) in the $23 \mathrm{~S}$ rRNA by the Erm methylases (Gaynor and Mankin, 2003). This dimethylation not only prevents macrolide binding, but also confers resistance to lincosamide and streptogramin antibiotics (Tait-Kamradt et al., 2000; Gaynor and Mankin, 2003). So far, up to 40 plasmid and transposon-borne determinants (erm genes) of the Erm methylases with four major classes $(\mathrm{erm} A, \mathrm{erm} B, \operatorname{erm} C$, and $\mathrm{erm} F / A)$ have been reported in pathogenic bacteria (Weisblum, 1995; TaitKamradt et al., 1997; Roberts et al., 1999) including isolates from finfish aquaculture environments (Peteersen and Dalsgaard, 2003; Shah et al., 2012; Di Cesare et al., 2012; Munoz-Antienza et al., 2013). Lincosamides are inactivated by lincosamide nucleotidyl transferases encoded by $\ln u A$ (formerly $\operatorname{lin} A$ ) and $\ln u B$ (formerly $\operatorname{lin} B$ ) genes (Roberts et al., 1999; Lerclerq, 2002). Recently, Si et al. (2015) reported cooccurrence of $\ln u B$ gene with other resistance genes in bacterial plasmids. A rarely detected $m p h C$ gene encoding phosphotransferases which also modify macrolide has been reported (Matsuoka et al., 1998). The efflux proteins are encoded by the plasmid-borne genes $m r S A$ and $m e f A$ (Ross et al., 1990; Kataja et al., 2000; McGee et al., 2001). Innate genes eat and sal $A$ encoding proteins have been reported to confer resistance to macrolides and lincosamides including pleuromutilins and streptogramins (Isnard et al., 2013; Hot et al., 2014)

There are reports on resistance to macrolides and lincosamide in ACF aquaculture isolates. Kumar et al. (2012) reported $100 \%$ resistance to erythromycin and lincomycin among $F$. columnare isolates from ACF in India. In Nigeria, $47.1 \%, 9.1 \%, 85.7 \%, 66.7 \%$ and $100 \%$ resistance to erythromycin among E. coli, Pseudomonas, Salmonella, Staphylococcus and Edwardsiella isolates, respectively, from ACF was reported by Efuntoye et al. (2012). In Bangladesh, Nahiduzzaman et al. (2000) reported $60 \%$ and $80 \%$ resistance to erythromycin among Aeromonas and Pseudomonas isolates, respectively, from ACF aquaculture. A study in Malaysia reported $100 \%$ resistance to lincomycin among Flavobacterium, E. tarda, Hafnia alvei, P. aeruginosa and A. hydrophila isolates from ACF (Musa et al., 2009).

\section{Glycopeptide resistance}

Glycopeptides are bactericidal agents which kill bacteria by binding to the $N$-acyl-d-Ala-d-Ala termini of peptidoglycan and its precursor lipid II (Mendez-Alvarez et al., 2000; Yim et al., 2014). This binding effectively sequesters the substrate for two key enzymes critical to cell wall synthesis: the transglycosylases that transfer the $N$-acetyl-muramic acid- $N$ acetyl-glucosamine pentapeptide subunits from lipid II to the anchored cell wall, and the D, D-transpeptidases that crosslink strands of peptidoglycan (Yim et al., 2014). The result is inability to grow, rigidified cell wall and cell death (Sujatha and Praharaj, 2012; Yim et al., 2014). The mechanism of bacterial resistance to glycopeptides is by formation of abnormal peptidoglycan receptors (by precussors D-ala-D-lactate which has 1000 fold decreased glycopeptides affinity or D-ala-Dserine which has 6 times decreased glycopeptide affinity) with reduced glycopeptide affinity; this results in decreased binding of glycopeptides and decreased inhibition of cell wall synthesis (Cooper et al., 2000; Sujatha and Praharaj, 2012). Glycopeptide determinants are chromosomal-borne gene clusters van $A, \operatorname{van} B, \operatorname{van} C$, vanD, vanE, van $G$, van $L$, van $M$ and $\operatorname{van} N$ encoding the corresponding resistance phenotypes which are either inducible (use/exposure selection) and characterized by high-level (i.e. MIC of $64-1000 \mu \mathrm{g} / \mathrm{ml}$ ) or lowlevel (i.e. MIC of $8-32 \mu \mathrm{g} / \mathrm{ml}$ ) vancomycin resistance; or constitutive, non-inducible intrinsic (VanC1-3) (Depardieu et al., 2004; Courvalin, 2006; Lebreton et al., 2011; Sujatha and Praharaj, 2012).

The van genes have been associated with transposon Tn1546 (Sujatha and Praharaj, 2012). The van $A$ (vanHAX) and $\operatorname{van} B\left(\operatorname{van}_{B} B X_{B}\right)$ genes encode for 3 enzymes: a dehydrogenase (VanH/VanH $\mathrm{B}_{\mathrm{B}}$ phenotype) which reduces pyruvate to D-Lactate, a ligase (VanA/VanB phenotype) which synthesizes D-alanine-D-lactate, and a dipeptidase (VanX/VanX $X_{B}$ phenotype) which hydrolyses D-alanine-Dalanine precussors (Arthur and Quintiliani, 2001; Sujatha and Praharaj, 2012). While there is no report in available literature with regards to the presence of van genes in finfish aquaculture, it is known that vancomycin resistance is critical in Enterococcus (i.e. vancomycin-resistant enterococci [VRE]), a commensal bacterium inhabiting the gut of humans and animals, and also highly adapted to varying environments (Werner et al., 2013). Enterococci have been reported in tropical freshwater finfish aquaculture (Petersen and Dalsgaard, 2003) and it has also been reported to be highly prevalent in ACF aquaculture (Amanda and Nwaka, 2013). Since human and animal wastes easily find their way into ACF aquaculture in developing countries, there is a high likelihood that enterococcal isolates from ACF aquaculture systems would habour van genes. Nevertheless, Kumar et al. (2012) reported 100\% resistance to vancomycin among F. columnare isolates from ACF in India.

\section{Phenicol resistance}

Phenicols are broad-spectrum bacteriostatic agents which inhibit bacterial protein biosynthesis by reversible binding to the $50 \mathrm{~S}$ subunit of $70 \mathrm{~S}$ bacterial ribosomes thus preventing peptide elongation (Schlunzen et al., 2001; Schwarz et al., 2004; Miranda et al., 2013). Chloramphenicol and its synthetic fluorinated analog florfenicol are phenicols that are or have been used in aquaculture (Armstrong et al., 2008; Miranda et al., 2013). Acetylation of the drug via different types of chloramphenicol acetyltransferases (CATs) has been the most common mechanism of chloramphenicol resistance (Schwarz 
et al., 2004; Miranda et al., 2013). Other mechanisms of bacterial resistance to chloramphenicol include: expression of efflux systems, inactivation by phosphotransferases, mutations of the target site and permeability barriers (Shaw, 1983; Murray and Shaw, 1997; Schwarz et al., 2004). The replacement of a hydroxyl group with a fluorine atom protects florfenicol from inactivation by CATs (Shaw and Leslie, 1991; Schwarz et al., 2004). Thus, chloramphenicol-resistant strains in which resistance is exclusively based on CATs activity, is susceptible to florfenicol (Cannon et al., 1990; Schwarz et al., 2004). The CATs are encoded by the cat gene while the genes $\mathrm{cml}$ and $\mathrm{cmr}$ codify chloramphenicol efflux proteins (exporters) (Schwarz et al., 2004). These chloramphenicol determinants have been associated with mobile genetic elements such as plasmids and transposons (Desomer et al., 1992; Nagy et al., 1997; Tauch et al., 1998; Schwarz et al., 2004). Chloramphenicol determinants cat 1 , cat 2 , cat 3 and cat 4 genes have been reported in isolates from finfish aquaculture (Shah $e t$ al., 2012; Ng et al., 2014).

Mechanisms of bacterial resistance to florfenicol include: specific and non-specific drug transporters, RNA methyltransferases, and specific hydrolases (Paulsen et al., 1996; Schwarz et al., 2004; Miranda et al., 2013). The efflux proteins that export florfenicol out of the cell are encoded by genes flo $R$ and fex $A$ which belong to the major facilitator superfamily (Schwarz et al., 2004; Miranda et al., 2013). The radical Sadenosine methionine (SAM) superfamily of protein, encoded by an RNA methyltransferase gene $c f r$, has been reported to inhibit ribose methylation and thereby causes resistance to florfenicol, chloramphenicol, and clindamycin (Sophia et al., 2001; Long et al., 2006; Miranda et al., 2013). Reports abound on the occurrence of $f l o R$ gene in aquaculture settings (Miranda et al., 2013). Bacterial isolates from aquaculture have also been reported to habour plasmids containing $f l o R$ gene and other genes such as in tet $Y$, sul2, qnr and strA-strB (Gordon et al., 2008; Buschmann et al., 2012; Miranda et al., 2013). The presence of $f l o R$ gene in aquaculture is critical because it is among the five antibacterial resistance genes which constitute the main component of the multidrug resistance region of Salmonella genomic island 1 (SGI1) (Ahmed et al., 2007; Ishida $e t$ al., 2010). Thus, the presence of the floR gene in aquaculture could result in its spread in Salmonella colonizing humans and animals following consumption of fish habouring bacteria with floR gene (Smith, 2008).

The use of chloramphenicol in food animals, including aquaculture, was banned in European countries in 1994 because it causes dose-independent irreversible aplastic anaemia in humans (Schwarz et al., 2004). Because the effect (aplastic anaemia) is dose-independent, the "non-observed effect level" (NOEL) (the dose at and below which adverse effects do not occur) and the "maximum residue level" (MRL) the maximum level of antibacterial residues acceptable in carcasses at slaughter without any adverse effect on public health, deduced from NOEL, could not be determined (Schwarz et al., 2001; Schwarz et al., 2004). Therefore, florfenicol, considered to be more active and safer than chloramphenicol (since florfenicol has not shown dose-independent aplastic anaemia in animals) is allowed and commonly used in aquaculture in developed countries (Schwarz et al., 2004; Armstrong et al., 2005).
Detection of chloramphenicol residues and/or chloramphenicol-resistant organisms in aquaculture products resulted in international ban of the products in Europe (Hatha et al., 2005; Nget al., 2014).

In ACF aquaculture, resistance to chloramphenicol has been reported more than to florfenicol. Laith and Najiah (2013) reported $9.09 \%$ resistance to florfenicol among $A$. hydrophila isolates from ACF in Malaysia. In Nigeria, Efuntoye et al. (2012) reported $82.4 \%, 36.4 \%, 57.1 \%$ and $53.3 \%$ resistance to chloramphenicol among E. coli, Pseudomonas, Salmonella and Staphylococcus isolates respectively, from ACF. A similar study in Nigeria reported $78 \%$ resistance to chloramphenicol among Aeromonas isolates from ACF (Anyanwu et al., 2014). In Bangladesh, chloramphenicol resistance of 20\% and 40\% among Aeromonas and Pseudomonas isolates from rearing water and ACF, respectively, was reported (Nahiduzzaman et al., 2000). These reports on chloramphenicol resistance in ACF aquaculture setting may be a pointer that chloramphenicol is used in ACF aquaculture, so it calls for concern. The use of chloramphenicol in ACF aquaculture may be due to the high cost and/or unavailability of florfenicol in LMIFDCs where ACF is farmed, a situation that results in resorting to the use of chloramphenicol by the farmers. However, the florfenicol resistance reported in ACF aquaculture could be as a result of selection pressure due to inclusion of florfenicol in commercial fish feed at subtherapeutic dose (Hayes et al., 2013). This is evidence for lax control of antibacterial use in ACF-rearing countries (Cabello et al.,2013).

\section{Nitrofuran resistance}

Nitrofurans (e.g. nitrofurantoin, furazolidone) are old broad-spectrum bactericidal agents (Sandegeren et al., 2008). Reduction of nitrofurans by bacterial flavoproteins to reactive intermediates which subsequently inactivate or alter bacterial ribosomal proteins and other macromolecules results in bacterial cell death (McCalla et al., 1970; Petersen et al. 1979; Sandegeren et al., 2008). The mechanisms of action of nitrofurans are yet to be fully understood. The mechanism of bacterial resistance to nitrofurans is by production of nitroreductases I and II which are encoded by $n f s A$ and $n f s B$ genes, respectively (McCalla et al., 1975; Whiteway et al., 1998; Sandegeren $e t$ al., 2008). In Europe, the use of nitrofurans together with nitroimidazoles in food-producing animals, including aquaculture, was banned in 1993 because their NOEL and MRL could not be determined (Schwarz et al., 2004). In 1995, the use of nitrofurans in livestock was completely prohibited due to concerns about the carcinogenicity and mutagenicity of the drug residues and their potential harmful effects on humans (Vass et al., 2008).

In India, $100 \%$ resistance to nitrofuranoin among $F$. columnare isolates from ACF have been reported (Kumar et al., 2012). In Nigeria, $37.5 \%$ of streptococci and $87.5 \%$ of Salmonella and staphylococcal isolates from ACF were reported to be resistant to nitrofurantoin (Adedeji et al., 2013). Another Nigerian study recorded 17.6\%, 27.3\%, 28.6\% and 6.7\% resistance to nitrofurantoin among E. coli, Pseudomonas, Salmonella and Staphylococcus isolates, respectively, from ACF 
8

(Efuntoye $e t$ al., 2012). A Malaysian study observed 27.2\% nitrofurantoin resistance among $A$. hydrophila isolates from ACF (Laith and Najiah, 2013) while another Malaysian study reported $14.3 \%$ resistance to furazolidone among $7 \mathrm{E}$. tarda isolates from polycultured ACF (Wei et al., 2011). These reports on resistance to nitrofurans in ACF aquaculture environments suggest that the determinants of nitrofurans may have entered into ACF aquaculture system from other anthropogenic sources, or that these drugs are used in livestock and/or ACF aquaculture systems. This calls for concern because of the health impacts of these drugs when their residues are found in aquaculture products (Schwarz et al., 2004).

\section{Sulfonamide and diaminopyrimidine resistance}

Sulfonamides and diaminopyrimidines are bacteriostatic agents which inhibit nucleic acid synthesis by competitive inhibition of dihydropteroate synthase (DHPS) and dihydrofolate reductase (DHFR), enzymes involved in the synthesis of tetrahydrofolic acid, a necessary factor for the synthesis of folate, a co-enzyme involved in the synthesis of purines and pyrimidines (Then, 1982; Richards et al., 1996; Abatcha et al, 2014). Sulfonamides are analogs of $p$ aminobenzoic acid hence they inhibit DHPS, an enzyme that catalyzes an early step in folate synthesis while diaminopyrimidines inhibits DHFR, an enzyme that catalyzes the final step in folate synthesis (Normark and Normark, 2002; Bukhart and Bukhart, 2009; Abatcha et al., 2014). Sulfonamides and diaminopyrimidines (e.g., trimethoprim) act synergistically, and when combined they are called potentiated sulfonamides (Richards et al., 1996). In aquaculture, sulphamethoxazole/trimethoprim combination is commonly used because of its broad-spectrum activity (Serrano, 2005; Muziasari et al., 2014).

Mechanism of bacterial resistance to sulfonamides is by mutations in the chromosomal DHPS gene folP, or through acquisition of an alternative DHPS gene sul whose product has a low affinity for sulfonamides (Petersen and Dalsgaard, 2003; Hoa et al., 2010) The sulfonamide determinants sull, sul2 and sul3 genes encoding DHPS have been reported in bacteria, including isolates from aquaculture environments (Lopez et al., 1987; Hoa et al., 2008; Su et al., 2011; Suzuki et al., 2013; Muziasari et al., 2014; Tajkbash et al., 2015). The sull and sul2 genes were reported to be more prevalent than sul 3 gene in aquaculture environment (Hoa et al., 2008; Hoa et al., 2010; Su et al., 2011; Suzuki et al., 2013; Takjbash et al., 2015). The sul genes are associated with the chromosome more than the plasmids (Hoa et al., 2008). The occurrence of sull and sul2 genes in class 1 integrons in bacterial isolates from aquaculture environment has been reported (Su et al., 2011; Muziasari et $a l$., 2014). The $d f r$ gene is the determinant for trimethoprim and it is also associated with class 1 integrons (Shah et al., 2012). The $d f r$ gene encodes production of DHFR thereby countering the inhibitory effect of trimethoprim (Szczepanowski et al., 2009). Several variants of $d f$ r gene such as dfrA1, dfrA2 dfr A5, dfrA7, dfrA12, dfrA15 and dfrA17 have been reported in bacteria, including isolates from finfish aquaculture environment (Ishida et al., 2010; Su et al., 2011; Shah et al., 2012; Muziasari et al., 2014). Co-occurrence of $d f$ r gene with aad, orff and cat genes in class 1 integrons have been reported in isolates from finfish aquaculture (Ishida et al., 2010; Su et al., 2011). Okoh et al. (2010) reported that Vibrio isolates from wastewater effluents harboured $d f r$ genes; these are potential contaminants of aquaculture because they are often present in sewage and hence water bodies (Fawell and Nieuwenhuijsen, 2003).

Resistance to sulfonamide and potentiated sulfonamide in ACF aquaculture environments has been reported. In Nigeria, Efuntoye et al. (2012) recorded 9.1\%, 57.1\%, 20\% and 100\% resistance to sulfamethoxazole among Pseudomonas, Salmonella and Staphylococcus and E. tarda isolates from ACF, respectively. Another Nigerian study reported 100\% resistance to sulfamethoxazole/trimethoprim among Staphylococcus and Streptococcus isolates from ACF (Adedeji et al., 2011). Nahiduzzaman et al. (2000) reported 30\% resistance to sulfamethoxazole among Aeromonas and Pseudomonas isolates from rearing water and ACF hybrid in Malaysia while Wei $e t$ al. (2011) reported $85.7 \%$ resistance to sulfamethoxazole among $E$. tarda isolates from polycultured ACF.

\section{$\beta$-lactam resistance}

$\beta$-lactams are bactericidal agents which kill bacteria by interfering with the cross-linking of penicillin binding protein (PBPs) (i.e. tanspepidases and carboxypeptidases) resulting in the synthesis of a defective peptidoglycan layer, and hence fragile spheroplast for Gram-negatives or cells easily autolyzed by lipotechoic acid for Gram-positives (McManus, 1997; Greenwood, 2000; Armstong et al., 2005; Tenover, 2006). $\beta$ lactams which include the penicillins, cephalosporins $\left(1^{\text {st }}, 2^{\text {nd }}\right.$, $3^{\text {rd }}$ and $4^{\text {th }}$-generations), monobactams, aztreonam, cephems, cephamycins, and carbapenems are differentiated by the number of the cyclic amide $\beta$-lactam ring in their structure (Bradford et al., 1999; Greenwood, 2000; Urmunova, 2015). The $\beta$-lactams are the most commonly used therapeutic class of antimicrobials for treatment of bacterial infection because of their broad antibacterial spectrum and excellent safety profile (Piscitelli et al., 2011; Abdallah et al., 2015). This may have resulted in use (exposure) selection pressure and evolution of diverse resistance mechanisms by bacterial organisms to this class of antibacterial agents (Abdallah et al., 2015). Mechanisms of bacterial resistance to $\beta$-lactam include: production of $\beta$ lactamases which hydrolyze the amide cyclic bond ( $\beta$-lactam ring) forming penicilloic or cephalosporic acid, change in the permeability of the cell wall, expression of active efflux pump, gene mutation and alteration of penicillin binding protein (PBP) receptors (Livermore and Brown 2001; Livermore and Woodford, 2006; Urmunova, 2015).

Production of $\beta$-lactamases is by far the major mechanism of $\beta$-lactam resistance in bacterial organisms (Livermore and Brown, 2001; Abdallah et al., 2015). B-lactamases are distinguished by their structure and function; they are grouped according to the Ambler and Bush-Jacoby-Medeiros classifications (Bush and Jacoby, 2010; Urmunova, 2015). Penicillinase and cephalosporinases mediate resistance to penicillins, $1^{\text {st }}$ - and $2^{\text {nd }}$-generation cephalosporins (Livermore and Brown, 2001; Wilke et al., 2005; Bush and Jacoby, 2010). The extended-spectrum $\beta$-lactamases (ESBLs) (i.e., Cefotaximase Munich [CTX-M], Psendomonas aeruginosa $\beta$ - 
lactamases [PER], Klebsiella pnuemoniae carbapenemase [KPC], New Delhi metallo- $\beta$-lactamase [NDM], Temoneira [TEM], sulfhydryl variable [SHV], Guiana extended-spectrum $\beta$-lactamases [GES] and Oxacillinase type $\beta$-lactamase [OXA]types) are point-mutational variants of the classical $\beta$ lactamases (especially the SHV and TEM) belonging in the molecular class $\mathrm{A}$ of Ambler classification and group $2 \mathrm{be}$ of Bush-Jacoby-Medeiros classification (Paterson and Bonomo, 2005; Bush and Jacoby, 2010; Zurfluh et al., 2013). The carbapenemases (OXA-48, Imipinem $\beta$-lactamases [IMP], Verona integrons-encoded $\beta$-lactamase [VIM], Sao Paulo metallo- $\beta$-lactamases (SPM), NDM and KPC-types) mediate resistance to all classes of antibacterial agents including carbapenem which is the only remaining class of therapeutic agents that can kill ESBL-producing organisms (Abraham et al., 2013). Superbugs are carbapenemase-producing organisms which are resistant to all known therapeutic agents, infection by them are often untreatable and fatal (Johnson and Woodford, 2012; Bush, 2013). Resistance to $\beta$-lactam- $\beta$ lactamase inhibitors (e.g., amoxicillin/clavulanic acid) occur following hyper production of class A $\beta$-lactamases (TEM- 1 or $S H V-1)$, production of class $D$ plasmid-mediated enzyme, chromosomal or plasmidic class $C \beta$-lactamase, ampicillinase $C$ (AmpC) $\beta$-lactamases/cephalosporinases and/or modification of outer membrane permeability (Chaibi et al., 1999; Dwarz and Bonomo, 2010).

The bla genes encode the $\beta$-lactamases. Several $\beta$-lactamase determinants such as bla $a_{\mathrm{TEM}-104}, b l_{a_{\mathrm{TEM}-1}}, b l_{\mathrm{SHV}}$ - non-ESBL $\left(\right.$ bla $\left._{\mathrm{SHV}-1}, b l_{\mathrm{SHV}-11}, b l a_{\mathrm{SHV}-25}, b l a_{\mathrm{SHV}-26}\right)$ and ESBL (bla $a_{\mathrm{SHV}-12}$,

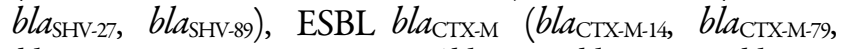
bla $\left.a_{\mathrm{CTX}-\mathrm{M}-15}\right)$, AmpC $\beta$-lactamase (bla $\left.{ }_{\mathrm{CMY}-2}\right), b_{a_{\mathrm{LEN}-17}}$ and bla $_{\mathrm{LEN}-26}$ genes have been reported in bacteria, including isolates from finfish aquaculture environment (Ishida et al., 2010; Chikwendu et al., 2011; Jiang et al., 2012; Shah et al., 2012; Ryu et al., 2012; Pereira et al., 2013; Abgottspon et al., 2014 Chikwendu et al., 2014). The bla $a_{\mathrm{TEM}}$ is the most prevalent bla gene reported in finfish aquaculture (Jiang et al., 2011; Chikwendu et al., 2011). The presence of ESBL determinants in aquaculture is a matter of growing concern because they confer co-resistance to many other classes of therapeutic agents including aminoglycosides, potentiated sulfonamides, fluoroquinolones, tetracyclines, and phenicols (Gniadowlski, 2001; Coque et al., 2008; Abraham et al., 2014). Currently, the bla СтХ-M-15 gene is the most predominant ESBL determinants reported in humans (Urmunova, 2015), thus its presence in aquaculture can increase the prevalence in humans and vice versa. Carbapenem determinants include: bla $a_{\mathrm{OXA} 48,}$ bla $a_{\mathrm{NDM}-1,}$ bla $a_{\mathrm{KPC}}$ and bla ${ }_{\mathrm{VIM}}$ genes (Ellington et al., 2007; Poirel et al., 2011; Zurfluh et al., 2013). Ishida et al. (2010) detected bla OXA- $_{\text {- }}$ 90 in two enterobacterial isolates from freshwater finfish aquaculture in Egypt. Contamination of water sources with human sewage which is of high possibility in developing countries has been suggested to be a crucial source of ESBL and carbapenem determinants in aquatic systems and aquaculture (Mesa et al., 2006; Fontes et al., 2011; Jiang et al., 2012; Araujo et al., 2014). This is of tremendous consequence as dissemination of these genes would result in emergence of superbugs in aquaculture settings. The presence of ESBL and carbapenem determinants in aquaculture can result in fast global spread of the genes through international travel and importation since the genes are associated with integrons, transposons and other mobile genetic elements (Jiang et al., 2011; Abraham et al., 2014).

Methicillin-resistant staphylococci (MRS) are multidrugresistant exhibiting resistance to other classes of antibacterial agents including aminoglycoside, fluoroquinolones, lincosamides, potentiated sulfonamide and tetracycline (Morris et al., 2006; Chambers, 1997; Febler et al., 2011). MRS has been reported in staphylococcal isolates from finfish aquaculture (Albuquerque et al., 2007; Soliman et al., 2011). Recent studies detected staphylococci habouring mec $A$ gene in fish products; typing of the $S$. aureus protein a $(s p a)$ in the isolates revealed that they belonged to the zoonotic clones (Hammad et al., 2012; Sergelidis et al., 2014). Therefore, it is possible that human carriers contaminated the fish products and aquaculture with MRS also known to colonize external surfaces and mucous membranes of humans (Fitzgerald, 2012; Schamburg et al., 2013; Sergelidis et al., 2014). Human colonization in developing countries is high and having being reported to colonize livestock (Wulf and Voss, 2008), MRS can easily enter ACF aquaculture. Thus, the presence of $\mathrm{MRS} / \operatorname{mec} A$ gene in aquaculture is another $\beta$-lactam resistance issue of serious global concern.

Many investigators have reported $\beta$-lactam resistance among different bacterial genera/species in the ACF aquaculture. Using microdilution method to determine minimum inhibitory concentration (MIC), Wei et al. (2011) recorded $42.9 \%$ resistance to ampicillin among $7 E$. tarda isolates from ACF in a Malaysian polyculture. Another Malaysian study reported $100 \%$ ampicillin resistance among $A$. hydrophila isolates from ACF (Laith and Najiah, 2013). In Nigeria, Anyanwu et al. (2014) also reported $100 \%$ and $20 \%$ resistance to ampicillin and amoxicillin/clavulanic acid resistance among Aeromonas species isolated from ACF. Another Nigerian study also reported $100 \%$ resistance to ampicillin among Aeromonas, Alcaligenes, Citrobacter, Enterobacter, Escherichia, Klebsiella, Proteus, Pseudomonas, Salmonella, Serratia, Micrococcus, Staphylococcus, Streptococcus, and Bacillus isolates from rearing water, sediments and ACF (Ekundayo et al., 2014). Efuntoye $e t$ al. (2012) reported $82.4 \%, 63.6 \%, 42.9 \%$ and $73.3 \%$ resistance to ampicillin, and $41.2 \% 54.5 \%, 57.1 \%$, and $66.7 \%$ resistance to amoxicillin among E. coli, Pseudomonas, Salmonella and Staphylococcus isolates, respectively, from ACF in Nigeria. Also, Adedeji et al. (2011) reported $37.5 \%$ resistance to ampicillin among Salmonella isolates from ACF in Nigeria. Staphylococcus and Streptococcus isolates obtained in the study exhibited 100\% and $75 \%$ resistance to amoxicillin. In India, Kumar et al. (2012) reported $100 \%$ resistance of F. columnare isolates from ACF to ampicillin, amoxicillin/clavulanic acid, amoxicillin, cloxacillin and penicillin G. However, the $100 \%$ resistance to ampicillin recorded in some of the reports in ACF aquaculture may be related to the inherent ampicillin-resistance in Aeromonas species except for $A$. trota which is susceptible to ampicillin (Janda and Abott, 2010). The CITM cluster gene encoding AmpC $\beta$-lactamase which hydrolyses $\beta$-lactams, including ampicillin, has also been reported in $E$. coli isolate from aquaculture (Van et al., 2008).

Reports in ACF aquaculture revealed that there is ongoing resistance to extended spectrum $\beta$-lactams and carbapenems. 
10

Kumar et al. (2012) reported that $F$. columnare isolates from ACF in India showed 100\% resistance to cefotaxime, cefoxitin and ceftazidime. Anyanwu et al. (2014) reported 71\% resistance to ceftriaxone among Aeromonas isolates from ACF in Nigeria. Using imipineme-EDTA method, Khainar et al. (2013) detected metallo- $\beta$-lactamase (MBLs)-producing $P$. aeruginos a from ACF in India. Emergence of MBLs-producing $P$. aeruginosa in ACF aquaculture is alarming and reflects excessive use of antibacterial agents in the system (Khainar $e t$ al., 2013; Johnson and Woodford, 2012). This is a public health emergency because MBLs are carbapenemases which mediate resistance to all antibacterial agents. This calls for concern and for early detection and prompt infection control measures to prevent further spread of MBLs to other Gramnegative rods (Khainar et al., 2013; Abraham et al., 2014). The reported resistance to $\beta$-lactams in ACF aquaculture could be related to the fact that this class of antibacterial agents is frequently used in human and veterinary medicine in LMIFDCs due to their affordability and over-the-counter availability (Laximarayan et al., 2014). It is projected that in few years to come, the prevalence of ESBL and carbapenem resistance in ACF aquaculture environments may outnumber that in any other environmental setting. This prediction is feasible because of the current rise in the use of extendedspectrum $\beta$-lactams and carbapenems in human and veterinary medicine especially in developing countries.

\section{Multiple antibacterial resistance in African catfish aquaculture}

Multiple antibacterial resistance (MAR) has been defined as resistance to three or more classes of antibacterial agents by an isolate (Tenover, 2006). Some investigators regard isolates that exhibit resistance to two or more different classes of antibacterial agents to be multidrug-resistant. Multidrug resistant genotyopes are detected by the presence of two or more resistance genes in their genome (Ishida et al., 2010). Nevertheless, some investigators (Miranda and Zimmelman, 2002; Su et al., 2011) of AR in ACF aquaculture evaluated the health risk associated with $A R$ phenotypes by calculating the multiple antibacterial resistance (MAR) index using the formular first described by Krupperman (1983). The MAR index, when applied to a single isolate, is defined as $a / b$, where a represents the number of antibacterial agents to which the isolate was resistant, and $b$ represents the number of antibacterial agents to which the isolate was exposed. If indexing is applied to a sample from which several isolates were taken, the index of the sample would be $a /\left(b^{*} c\right)$, where $a$ is the aggregate antibacterial resistance score of all isolates from the sample, $b$ is the number of antibacterial agent, and $\mathrm{c}$ is the number of isolates from the sample. When the use of antibacterial agents in an aquaculture is seldom or low (i.e. low-risk exposure), the MAR index value is usually $\leq 0.2$, whereas in a farm where antibacterial agents are frequently used (i.e. high risk of exposure), the MAR index value is usually >0.2 (Jones et al., 1986; Wei et al., 2011; Laith and Najiah, 2013).

Varying MAR indexes have been reported for different bacterial isolates from ACF. In Malaysia, Musa et al. (2009) reported MAR index among different bacterial isolates from ACF such as Pseudomonas aeruginosa (0.24), Hafnia alvei (0.29), Flavobacterium (0.52), Edwardsiella tarda (0.42) and Aeromonas hydrophila (0.28). In another Malaysian study, Laith and Najiah, (2013) reported MAR index of 0.10-0.50 among Aeromonas hydrophila isolates from ACF. In Nigeria, 80\% of pooled Aeromonas, Pseudomonas, Micrococcus, Moraxella, Escherichia coli, Acinetobacter, Staphylococcus aureus, Proteus, Moraxella, Streptococcus faecalis and Shigella isolates from rearing water obtained from an ACF farm exhibited MAR (Torimiro et al., 2014). Anyanwu et al. (2014) also reported 96\% MAR among Aeromonas isolates from ACF in Nigeria.

\section{Impact of antibacterial resistance in African catfish aquaculture on the food chain and public health}

Antibacterial resistance in aquaculture has overwhelming impact on the food chain and public health (Heuer et al., 2009; Cabello et al., 2013; Vaz-Moreira et al., 2014). It has been observed that $\mathrm{AR}$ in aquaculture can easily enter the food chain undetected (WHO, 2014; Morrison and Rubin, 2015). This is because among a plethora of microorganisms in aquaculture environment, only few indicator organisms can easily be cultured unlike in livestock animals (Morrison and Rubin, 2015). Antibacterial-resistant organisms in ACF aquaculture can be transferred to humans (especially those with wounds) who come in direct contact with ACF aquaculture ecosystem. The bacterial population in fish rearing water is the same with those colonizing the fish (Cabello et al., 2013). Therefore, contact with fish rearing water or consumption of fish habouring ARO/ARGs can result in colonization with the organisms. Fish-farm workers or processing plant workers are more at risk of acquiring AROs since they are frequently exposed to contaminated water and/or fish in the aquaculture or in downstream handling of fish for food preparation (Harper, 2002; Petersen and Dalsgaard, 2003; Jacobs and Chenia, 2007). Due to poor infection control practices and sanitation often observed in developing countries, the AROs can be spread from person to person, magnifying the effect of their selection (Okeke and Edelman, 2001). The total mobile genetic elements (mobilomes) (i.e. water current-transported naked DNA, insertion sequences, transposons, integrative and conjugative elements [ICEs], insertion sequence with common regions [ISCR], integrons mobilized by plasmids, bacteriophages, conjugative transposons, and phage-like elements called gene transfer agents [GTA]) of aquatic bacteria transfer easily from aquaculture organisms to human and animal pathogens and vice versa (Kruse and Sørum, 1994; Jacobs and Chenia, 2007; Cabello et al., 2013). Movement of mobile genetic elements contributes to the emergence of novel genotypic and phenotypic variants (Canica et al., 2015).

Fish meal used as source of animal protein for livestock (especially poultry), may be produced using ACF which haboured AROs/ARGs or contaminated with the organisms by aquaculture workers. Following consumption, the AROs colonize livestock gut and subsequently transfer the resistomes to other organisms in the animal by horizontal transfer. The AROs are subsequently transferred to humans following ingestion of contaminated meat from the livestock or from other animals contaminated during slaughter. The colonized 
livestock can also discharge the AROs/ARGs into the terrestrial and/or aquatic environment as in IACF. Natural water bodies, aquatic animals and farm crops get contaminated or colonized with AROs which continue to recycle the resistomes, genomes and mobilomes across and within different environmental settings (Vaz-Moreira et al., 2014; Berendonk et al., 2015). Discharge of fish-rearing water loaded with AROs/ARGs into the environment can also result in contamination of farm crops and vegetations (Vaz-Moreira $e t$ al., 2014). Consumption of contaminated vegetation/crops by animals and humans represents risk to human and animal health (Vaz-Moreira et al., 2014; Berendonk et al., 2015). Runoffs can potentially carry AROs into natural freshwater bodies and subsequently into the food chain (Vaz-Moreira et al., 2014; Musefiu et al., 2015). With the rise in international travel now worsened by surging migrant crisis, genomes and resistomes emanating from ACF aquaculture can easily spread to other parts of the world, thereby increasing the mobilome in those places (Okeke and Edelman, 2001; Canica et al., 2015). Colonized individuals transfer AROs directly or indirectly to livestock and aquaculture (Cabello et al., 2013).

It is established that mobile genetic elements associated with ARGs of bacteria recovered from aquatic environment can share very high sequence homology to clinically important plasmids and ARGs (Venner-Jeffreys et al., 2009; Cabello et al., 2013). Thus, acquisition of ARGs from aquaculture pathogens can result in compromise and jeopardy of subsequent antibacterial therapy in colonized humans and animals (Heuer et al., 2009; Geser et al., 2011; Cabello et al., 2013), since most antibacterial agents used in humans are similar to those used in veterinary medicine and aquaculture (Gacia-Alvarez et al., 2012; Canica et al., 2015). The cost of treatment, morbidity and mortality often resulting from acquired AR especially when associated with multidrug resistance (such as VRE, MRS,
ESBL- and carbapenemase-producing organisms) is overwhelming. These multidrug-resistant organisms have been associated with most community-acquired, nosocomial and hospital-linked infections worldwide (Ewers et al., 2011; Kleinkuf et al., 2014). Plasmids harbouring multidrugresistance genes are highly promiscuous (Abraham et al., 2014), a factor that may facilitate their spread from ACF aquaculture to other environmental settings and vice versa. Thus, the flow of antibacterial resistance in ACF aquaculture and its subsequent impact on the food chain and public health is a continuous cycle (Fig. 2). Although not within the scope of this review, the fate of antibacterial residues in aquaculture sediment and their subsequent dissemination to natural water bodies by run-offs, leaching, exposure of organisms and development of resistance in other environmental settings have been severally reported (Hektoen et al., 1995; Kumerre, 2004; Armstrong et al., 2005; Cabello et al., 2013; Canica et al., 2015).

\section{Strategies for curbing antibacterial resistance in African catfish aquaculture}

Practicable ways of minimizing the emergence and spread of $\mathrm{AR}$ in $\mathrm{ACF}$ aquaculture include: good management strategies such as the use of good quality fish stock, reducing stocking densities, maintaining overall good environmental conditions ( $\mathrm{pH}$, dissolved oxygen, etc), the implementation of proper biosecurity measures, development of effective vaccines and vaccination programs, proper diagnosis of diseases before treatment, and the rotation of antibacterial agents in treatment of fish bacterial diseases (Smith, 2008; Miranda et al., 2013). Alternative strategies to combating bacteria such as bacteriophage and probiotics therapy have been applied in other types of finfish aquaculture (Defoirdt et al., 2011; Cruz et

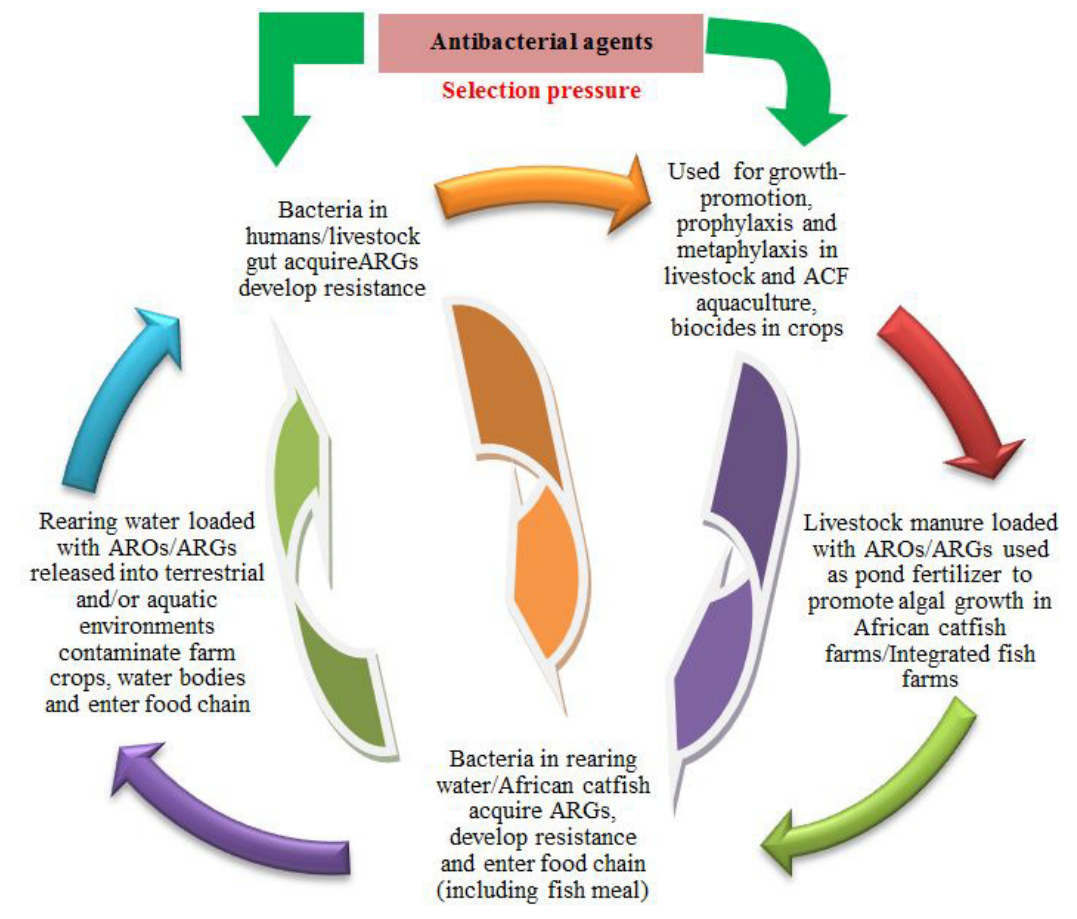

Fig. 2. Flow of antibacterial resistance [antibacterial-resistant organisms (AROs)/antibacterial resistance genes (ARGs)] in African catfish (ACF) aquaculture and impact on the food chain 
12

al., 2012; Ibrahem, 2015). Although bacteriophages are usually host (bacterial)-specific and have a narrow-spectrum of activity, a bacteriophage with broad-spectrum activity has been used in a shrimp aquaculture (Vinod et al., 2006; Defoirdt et al., 2011). Encouragingly, a recent study in India reported a novel bacteriophage therapy for controlling metallo- $\beta$-lacatamseproducing $P$. aeruginosa isolated from ACF (Khainar et al., 2014). The use of probiotics in combating AR in ACF aquaculture seems very promising (Cruz et al., 2012; Sihag and Sharm, 2012; Ige, 2013; Ibrahem, 2015), but its limitation is that the organisms may habour ARGs which can complicate the problem of AR in aquaculture (Khainar et al., 2014). Some researchers (Ogunshe and Olabode, 2009; Hamid et al., 2012; Olayinka and Afolabi, 2013) reported the isolation of bacterial organisms that have probiotic potential from ACF, but the applicability of these organisms in ACF aquaculture is yet to be realized. Defoirdt et al. (2011) reported other sophisticated alternative strategies such as genome manipulation and antivirulence therapy that can be used in place of antibacterial agents in combating bacteria in aquaculture. Essential oils have also been reported to be potential alternative to antibacterial agents for combating bacteria in aquaculture (Romero et al., 2011; Chenia et al., 2015).

In the absence of vaccines, bacteriophage and probiotics therapy for ACF aquaculture for now, a rational use (i.e. adoption of treatment regimen that have improved clinical efficacy but that result in minimal selective pressure for emergence of resistant variants) of antibacterial agents can be helpful (Smith 2008). Although similar classes of antibacterial agents are used in human and veterinary medicine, rotation of antibacterial agents may be useful in reducing the chances of selection, co-selection and dissemination of AR (Miranda et al., 2013). The example of what happened in Europe on how AR (especially vancomycin-resistance) was controlled by minimizing their use in food-producing animals can be borrowed (Cogliani et al., 2011). However, because of the ease of transfer of AROs/ARGs from aquaculture environments to other ecosystems, the use of antibacterial agents in aquaculture is being discouraged (FAO/WHO/OIE, 2014). Therefore, efforts should be made by those responsible in countries where ACF is farmed to develop and register antibacterial agents for use in aquaculture and to develop strictly enforced policy guiding their use. Antibacterial resistance surveillance is the hallmark approach for controlling the crisis and for formulation of measures for mitigation. Those responsible should know that the long term effects of $A R$ is that, even in the absence of selective pressures, when the use of an antibacterial agents is banned from an aquaculture system, genes conferring low susceptibility to that agent will persist (Tamminen et al., 2011; Cabello et al., 2013; Vaz-Moreira et al., 2014).

\section{Concluding remarks}

The reviewed reports have shown that ACF aquaculture represent a reservoir of diverse $\mathrm{ARO}$ s which can habour variety of ARGs, many of which may be mobilized by lateral gene transfer. Numerous factors (particularly the use of antibacterial agents uncontrollably) are responsible for emergence of $\mathrm{AR}$ in ACF aquaculture, this relates to the fact that this fish species is mainly reared in less industrialized or developing countries (Okeke and Edelman, 2001; Cabello et al., 2013). Antibacterial resistance in ACF aquaculture impacts food chain and represents threat to animal and human health. The presence of wide variety of AROs especially the ESBLs-producing and carbapenemase-producing organisms in ACF aquaculture, is a cause for concerns as these organism can easily spread genes encoding multidrug resistance to other parts of the world and ecological niches. Change in dynamics of $A R$ and emergence of novel phenotypic and genotypic strains can occur following transfer of ARGs from ACF aquaculture environments to other places (Miranda et al., 2013). The economic and health impact of AR in ACF aquaculture could be disastrous if timely efforts are not made to curb this menace.

Indeed, rapid increase in ACF aquaculture makes it imperative that research needs with regards to the use of antibacterial agents and emergence and potential spread of AR are prioritized (Miranda et al., 2013). Adequate, science-based policies that contribute to sustainability of ACF aquaculture industry, implementation of antibacterial stewardship and minimize risks to public health should be based on the research. Because the spread of AR in aquaculture is facilitated by genetic elements, molecular studies are needed to explore the prevalence of ARGs in isolates from ACF aquaculture environments including in zoonotic aquaculture pathogens. Knowledge gap exists on the co-occurrence of AROs from ACF aquaculture environment with human pathogens, transfer rate of resistance between ACF aquaculture and clinically relevant bacteria, and epidemiology of AR in ACF aquaculture. The emergence and prevalence of AR bacteria in $\mathrm{ACF}$ aquaculture setting may be greater than the reports reviewed in this study since most studies in ACF aquaculture have been limited to demonstrating AR in culturable bacteria, which constitute only a small proportion of the total bacteria present in the aquatic environment (Bissett et al., 2006; Cabello et al., 2013). Surveillance studies on AR in ACF aquaculture are needed to provide information on trends and magnitude of resistance. This review is a call for the establishment of ACF aquaculture AR surveillance monitoring programmes and for stringent policy to control the use of antibacterial agents in ACF aquaculture.

\section{References}

Abatcha MG, Zakaria Z, Kaur DG, Thong KL (2014). A trends of Salmonella and antibiotic resistance. Advances in Life Science and Technology 17:9-21.

Abdallah HM, Wintermans BB, Reuland EA, Koek A, al Naiemi, Ammar AM, Mohamed AA, Vandenbroucke-Grauls CJME (2015). Extended-spectrum $\beta$-lactamase- and carbapenemaseproducing enterobacteriaceae isolated from Egyptian patients with suspected blood stream infection. PLoS ONE 10(5):e0128120.

Abgottspon H, Nüesch-Inderbinen MT, Zurfluh K, Althaus D, Hächler H, Stephan R (2014). Enterobacteriaceae with extendedspectrum- and pAmpC-type $\beta$-lactamase-encoding genes isolated from freshwater fish from two lakes in Switzerland. Applied and Environmental Microbiology 58(4):2482-2484.

Abraham S, Wong HS, Turnidge J, Johnson JR, Trott DJ (2014). Carbapenemase-producing bacteria in companion animals: a public health concern on the horizon. Journal of Antimicrobial Chemotherapy 69(5):1155-11557. 
Adedeji OB, Musefiu TA, Emikpe BO (2011). The antibiotic resistant patterns of bacterial flora of fish from different aquatic environments from Ibadan, South-west Nigeria. Advances in Environmental Biology 5(8):2039-2047.

Adedeji OB, Onwenefah M (2013). The antibiotic resistant patterns of bacterial flora of cultured catfish fed with poultry hatchery waste from selected farms in Ibadan, Nigeria. Researcher 5(9):3743.

Ahmed AM, Hussein AI, Shimamoto T (2007). Proteus mirabilis clinical isolate harbouring a new variant of Salmonella genomic island 1 containing the multiple antibiotic resistance region. Journal of Antimicrobial Chemotherapy 59:184-190.

Aires JR, Nikaido H (2005). Aminoglycosides are captured from both periplasm and cytoplasm by the AcrD multidrug efflux transporter of Escherichia coli. Journal of Bacteriology 187:19231929.

Albuquerque WF, Macrae A, Sousa OV, Vieira GHF, Vieira RHSF (2007). Multiple drug resistant Staphylococcus aureus strains isolated from a fish market and from fish handlers. Brazilian Journal of Microbiology 38:131-134.

Alderman DJ, Rosenthal H, Smith P, Steward J, Weston D (1994). Chemicals used in mariculture. ICES working group environmental interaction of mariculture, International Council for the Exploration of the Sea. Copenhagen, Denmark. ICES Cooperation Research Report 202, p 100.

Aly SM (2014). Antimicrobials use in aquaculture and their public health impact. Journal of Aquaculture Research and Development 5:247 doi:10.4172/2155-9546.1000247.

Amande TJ, Nwaka SU (2013). Bacterial flora of African catfish (Clarias gariepinus) harvested from ponds in Uyo South-south Nigeria. IOSR Journal of Environmental Science Toxicology and Food Technology 5(3):72-76.

Anyanwu MU, Chah KF, Shoyinka VS (2014). Antibiogram of aerobic bacteria isolated from skin lesions of African catfish cultured in Southeast, Nigeria. International Journal of Fisheries and Aquatic Studies 2(1):134-141.

Anyanwu MU, Chah KF, Shoyinka VS (2015). Evaluation of pathogenicity of motile Aeromonas species in African catfish. International Journal of Fishries and Aquatic Studies 2(3):93-98

Araujo CF, Silva DM, Carneiro MT, Asensi MD, Zahner V, Assef ADC (2014). Detection of KPC-producing bacteria in aquatic ecosystem from Rio de Janeiro. http://www.icaaconline.com /php/icaac2014abstracts/data/papers/2014/C-080.htm.

Armstrong SM, Hargrave BT, Haya K (2005). Antibiotic use in finfish aquaculture: modes of action, environmental fate, and microbial resistance. Hdb Environmental Chemistry, 5(Part M): 1-x doi: $10.1007 / b 136017$.

Arthur M, Quintiliani R (2001). Regulation of VanA- and VanB-type glycopeptide resistance in enterococci, Antimicrobial Agents and Chemotherapy 45(2):375-381.

Berendonk TU, Manaia CM, Merlin C, Fatta-Kassinos D, Cytryn E, Walsh F, Bürgmann H, Sørum H, Norström M, Pons M, Kreuzinger N, Huovinen P, Stefani S, Schwartz T, Kisand V, Baquero F, Martinez JL (2015). Tackling antibiotic resistance: the environmental framework. Nature Reviews in Microbiology 13:310-317.

Blaak H, Hamidjaja RA, van Hoek AHAM, de Heer L, Husman AM, Schets FM (2014). Detection of extended-spectrum betalactamase (ESBL)-producing Escherichia coli on flies at poultry farms. Applied and Environmental Microbiology 80(1):239-246.

Bostock J, McAndrew B, Richards R, Jauncey K, Telfer T, Lorenzen K, Little D, Ross L, Handisyde N, Gatward I, Corne I (2010). Aquaculture: global status and trends. Philosophical Transactions of Royal Society London B Biological Science 365:2897-2912.

Boxall AB, Fogg LA., Blackwell PA., Kay P, Pemberton EJ, Croxford A (2004). Veterinary medicines in the environment. Reviews of Environmental Contamination and Toxicology 180:1-91.

Burridge L, Weis JS, Cabello F, Pizarrro J, Bostick K (2010). Chemical use in salmon aquaculture: A review of current practices and possible environmental effects. Aquaculture 306(1-4):1-7

Burdett V (1991). Purification and characterization of tet(M), a protein that renders ribosomes resistant to tetracycline. Journal of Biological Chemistry 266:2872-2877.

Burkhart CG, Burkhart CN (2009). Overview of sulfonamides and related medications: query if mesalamine should be preferred over dapsone and sulfasalazine. The Open Dermatology Journal 3:6567.

Buschmann AH, Tomova A, López A, Maldonado MA, Henríquez LA, Ivanova L,Moy F, Godfrey HP, Cabello FC (2012). Salmon aquaculture and antimicrobial resistance in the marine environment. PLoS ONE 7:e42724.

Bush K (2013). Carbapenemases: partners in crime. Global Journal of Antimicrobial Resistance 1(1):7-16.

Bush K, Jacoby GA (2010). Updated functional classification of betalactamases. Antimicrobial Agents and Chemotherapy 54:969976.

Cabello FC (2006). Heavy use of prophylactic antibiotics in aquaculture: a growing problem for human and animal health and for the environment. Environmental Microbiology 8(7):11371144.

Cabello FC, Godfrey HP, Tomova A, Ivanova L, Dölz H, Millanao A, Buschmann AH (2013). Antimicrobial use in aquaculture reexamined: its relevance to antimicrobial resistance and to animal and human health. Environmental Microbiology 15(7):19171942.

Canica M, Manageiro V, Jones-DiasD, Clemente L, Gomes-Neves E, Poeta P, Dias E, Ferreira E (2015). Current perspectives on the dynamics of antibiotic resistance in different reservoirs. Research in Microbiology http://dx.doi.org/10.1016/j.resmic.2015.07.009.

Cannon M, Hartford S, Davies J (1990). A comparative study on the inhibitory actions of chloramphenicol, thiamphenicol, and some fluorinated derivatives. Journal of Antimicrobial Chemotherapy 26: 307-317.

Canu A, Leclercq R (2009). Macrolides and lincosamides. In: Mayers DL (Ed). Antimicrobial drug resistance: mechanisms of drug resistance. Humana Press USA pp 211-221.

Castanon JIR (2007). History of the use of antibiotic as growth promoters in European poultry feeds. Poultry Science $86(11): 2466-2471$. 
14

Cattoir V, Nordmann P (2009). Plasmid-mediated quinolone resistance in Gram-negative bacterial species: an update. Current Medical Chemistry 16:1028-1046.

Chaibi EB, Sirot D, Paul G, Labia R (1999). Inhibitor-resistant TEM $\beta$-lactamases: phenotypic, genetic and biochemical characteristics. Journal of Antimicrobial Chemotherapy 43:447-458.

Chambers HF (1997). Methicillin resistance in staphylococci: molecular and biochemical basis and clinical implications. Clinical Microbiological Reviews 10:781-791.

Chenia HY (2015). Antimicrobial activity of cinnamaldehyde, vanillin and Kigelia africana fruit extracts against fish-associated Chryseobacterium and Myroides spp. isolates. African Journal of Traditional Complementary and Alternative Medicine 12(3):5557.

Chikwendu CI, Ibe SN, Okpokwasili GC (2011). Detection of blaSHV and blaTEM beta-lactamase genes in multi-resistant Pseudomonas isolates from environmental sources. African Journal of Microbiology Research 5(15):2067-2074.

Chikwendu CI, Ibe SN, Okpokwasili GC (2014). Multiple antimicrobial resistance in Vibrio spp isolated from river and aquaculture water sources in Imo State, Nigeria. British Microbiology Research Journal 4(5):560-569.

Chopra I, Roberts M (2001). Tetracycline antibiotics: mode of action, applications, molecular biology, and epidemiology of bacteria. Microbiology and Molecular Biology Reviews 65:232-260.

Clausen R, York R (2008). Global biodiversity decline of marine and freshwater fish. Social Science Research 37(4):1310-1320.

Cogliani C, Goossens H, Greko C (2011). Restricting antimicrobial use in food animals: lessons from Europe. Microbe 6(6):274-279.

Cooper MA, Fiorini MT, Abell C, Williams DH (2000). Binding of vancomycin group antibiotics to $\mathrm{D}$-alanine and D-lactate presenting self-assembled monolayers. Bioorganic and Medicinal Chemistry 8(11):2609-2616.

Coque TM, Baquero F, Canton R (2008). Increasing prevalence of ESBL producing Enterobacteriaceae in Europe. European Surveillance 13(47):pii_19044.

Costa RA, de Carvalho FCT, Vieira RSHF (2012). Antibiotic resistance in Salmonella: a risk to tropical aquaculture. In: Kumar Y (Ed). Salmonella: a diversified superbug. InTech, Croatia.

Courvalin P (2006). Vancomycin resistance in Gram-positive cocci. Clinical and Infectious Diseases 42(1):S25-S34.

Cruz PM, Ibanez AL, Hermosillo CAM, Saad HCR (2012). Use of probiotics in aquaculture. International Scholarly Research Network in Microbiology doi:10.5402/2012/916845.

Defoirdt T, Sorgeloos P, Bossier P (2011). Alternatives to antibiotics for the control of bacterial disease in aquaculture. Current Opinion in Microbiology 14:251-258.

DeMoor IJ and Bruton MN (1988). Atlas of alien and translocated indigenous aquatic animals in southern Africa. South African National Scientific Programmes Report 114, South Africa.

Depardieu F, Kolbert M, Pruul H, Bell J, Courvalin P (2004). VanDtype vancomycin-resistant Enterococcus faecium and Enterococcus faecalis. Antimicrobial Agents and Chemotherapy 48(10): 38923904.
Desomer J, Vereecke D, Crespi M, van Montagu M (1992). The plasmid-encoded chloramphenicol-resistance protein of Rhodococcus fascians is homologous to the transmembrane tetracycline efflux proteins. Molecular Microbioloy 6:2377-2385.

Devi SJ, Murray CJ (1991). Cockroaches (Blatta and Periplaneta species) as reservoirs of drug-resistant salmonellas. Epidemiology and Infection 107:357-361.

Di Cesare A, Luna GM, Vignaroli C, Pasquaroli S,Tota S, Paroncini $P$, Biavasco F (2013). Aquaculture can promote the presence and spread of antibiotic-resistant enterococci in marine sediments. PLoS ONE 8(4): e62838.

Di Cesare A, Vignaroli C, Luna GM, Pasquaroli S, Biavasco F (2012). Antibioticresistant enterococci in seawater and sediments from a coastal fish farm. Microbial Drug Resistance 18: 502-509.

Drlica K, Zhao XL (1997). DNA gyrase, topoisomerase IV, and the $4-$ quinolones. Microbiological Reviews 61:377-392.

Dwarz SM, Bonomo RA (2010). Three decades of beta-lactamase inhibitors. Clinical Microbiological Reviews 23(1):160-201.

Efuntoye MO, Olurin KB, Jegede GC (2012). Bacterial flora from healthy Clarias gariepinus and their antimicrobial resistance pattern. Advance Journal of Food Science and Technology 4(3):121-125.

Ekine DI, Albert CO, Peregba TA (2012). Expenditure pattern for beef consumption in selected households in southern Nigeria. Developing Country Studies 2(7):1-5.

Ekundayo FO, Diyaolu DO, Fasakin EA (2014). Composition, distribution and antibiotic sensitivities of bacteria associated with cultured Clarias gariepinus (Burchell 1822). Malaysian Journal of Microbiology 10(2):72-79.

Ellington MJ, Kistler J, Livermore DM, Woodford N (2007). Multiplex PCR for rapid detection of genes encoding acquired metallo- $\beta$-lactamases. Journal of Antimicrobial Chemotherapy 59:321-322.

Ewers C, Grobbel M, Bethe A, Wieler LH, Guenther S (2011). Extended-spectrum beta-lactamases producing Gram-negative bacteria in companion animals: action is clearly warranted! Berliner und Münchener 94 Tierärztliche Wochenschrift 124, Heft $3 / 4$ : Seiten 9-101.

Food and Agricultural Organization (FAO)/Office of Infection and Epizootics (OIE)/World Health Organization (WHO) (2006). Report of a joint FAO/OIE/WHO expert consultation on antimicrobial use in aquaculture and antimicrobial resistance: Seoul, Republic of Korea.

Fawell J, Nieuwenhuijsen MJ (2003). Contaminants in drinking water environmental pollution and health. British Medical Bulletin 68(1):199-208.

Febler AT, Kadlec K, Hassel M, Hauschild T, Eidam C, Ehricht R, Monecke S, Schwarz S (2011). Characterization of methicillin resistant Staphylococcus aureus isolates from food and food products of poultry origin in Germany. Applied and Environmental Microbiology 77(20):7151-7157.

Fitzgerald JR (2012). Human origin for livestock-associated methicillin-resistant Staphylococcus aureus. mBio 3(2):e00082-12.

Fontes LC, Neves PR, Oliveira S, Silva KC, Hachich EM, Sato MIZ, 
Lincopan N (2011). Isolation of Pseudomonas aeruginosa coproducing metallo- $\beta$-lactamase SPM-1 and $16 \mathrm{~S}$ rRNA methylase $\mathrm{RmtD1}$ in an urban river. Antimicrobial Agents and Chemotherapy 55(6):3063-3064.

Food and Agricultural Organization (FAO) (2000). Food Agricultural Organization. Year Book, Rome.

Food and Agricultural Organization (FAO) (2008). Climate change implications for fisheries and aquaculture. In: The state of fisheries and aquaculture. FAO, Rome, Italy pp 87-91.

Furushita M, Shiba T, Maeda T, Yahata M, Kaneoka A, Takahashi Y, Torii K, Hasegawa T, Ohta M (2003). Similarity of tetracycline resistance genes isolated from fish farm bacteria to those from clinical isolates. Applied and Environmental Microbiology 69:5336-5342.

Garcia-Alvarez L, Dawson S, Cookson B, Hawkey P (2012). Working across the veterinary and human health sectors. Journal of Antimicrobial Chemotherapy 67:i37e49.

Gaynor M, Mankin AS (2003). Macrolide antibiotics: binding site, mechanism of action, resistance. Current Topics in Medicinal Chemistry 3:949-960.

Geser N, Stephan R, Kuhnert P, Zbinden R, Kaeppeli U, Cernela N, Haechler H (2011). Fecal carriage of extended-spectrum betalactamase-producing Enterobacteriaceae in swine and cattle at slaughter in Switzerland. Journal of Food Protection 74(3):446449.

Gniadkowski M (2001). Evolution and epidemiology of extendedspectrum beta-lactamases (ESBLs) and ESBL-producing microorganisms. Clinical Microbiology and Infection 7:597-608.

Gordon L, Cloeckaert A, Doublet B, Schwarz S, AgnèsBouju-Albert A, Ganière JP, Le Bris H, Le Flèche-Matéos A, Giraud E (2008). Complete sequence of the floR-carrying multiresistance plasmid pAB5S9 from freshwater Aeromonas bestiarum. Journal of Antimicrobial Chemotherapy 62:65-71.

Greenwood D (2000). Antimicrobial Chemotherapy, 4th edition. Oxford University Press, New York pp 1-220.

Hamid THTA, Khan AJ, Jalil MF, Azhar NS (2012). Isolation and screening of lactic acid bacteria Lactococcus lactis from Clarias gariepinus (African catfish) with potential use as probiotic in aquaculture. African Journal of Biotechnology 11(29):74947499.

Hammad AM, Watanabe W, Fujii T, Shimamoto T (2012). Occurrence and characteristics of methicillin-resistant and susceptible Staphylococcus aureus and methicillin-resistant coagulase-negative staphylococci from Japanese retail ready-to-eat raw fish. International Journal of Food Microbiology 156:286289.

Harper C (2002). Chemical resistance of pathogens in aquaculture. Aquaculture Magazine 28:51-52.

Hart CA, Kariuki S (1998). Antimicrobial resistance in developing countries. British Medical Journal 317(7159):647-650.

Hatha M, Vivekanandhan AA, Joice GJ, Christol (2005). Antibiotic resistance pattern of motile aeromonads from farm raised fresh water fish. International Journal of Food Microbiology 98:131134.
Hayes J (2013). Determination of florfenicol in fish feeds at high inclusion rates by HPLC-UV. Journal of AOAC International 96(1):7-11.

Haylor GS (1991). Controlled hatchery production of Clarias gariepinus (Burchell 1822): growth and survival of fry at high stocking density. Aquaculture Research 22(4):405-422.

Hektoen H, Berge JA, Hormazabal V, Yndestad M (1995). Persistence of antibacterial agents in marine sediments. Aquaculture 133(3):175-184.

Heuer H, Schmitt H, Smalla K (2011). Antibiotic resistance gene spread due to manure application on agricultural fields. Current Opinion in Microbiology 14:236e43.

Heuer OE, Kruse H, Grave K, Collignon P, Karunasagar I, Angulo FJ (2009). Human health consequences of use of antimicrobial agents in aquaculture. Clinical and Infectious Diseases 49:12481253.

Hoa PTP, Managaki S, Nakada N, Takada H, Anh DH, Viet PH, HienPH, Suzuki S (2010). Abundance of sulfonamide-resistant bacteria and their resistance genes in integrated aquacultureagriculture ponds, North Vietnam. In: Hamamura N, Suzuki S, Mendo S, Barroso CM, Iwata $H$, Tanabe $S$ (Eds). Interdisciplinary Studies on Environmental Chemistry Biological responses to contaminants pp 15-22.

Hoa PTP, Nonaka L, Viet PH,Suzu S (2008). Detection of the sul1,sul2, and sul3 genes in sulfonamide-resistant bacteria from wastewater and shrimp ponds of north Vietnam. Science of the Total Environment 405(1-3):377-384.

Hooper DC (2001). Mechanisms of action of antimicrobials: focus on fluoroquinolones. Clinical and Infectious Diseases 32(Suppl 1):S9-S15.

Hot C, Berthet N, Chesneau O (2014). Characterization of sal(A), a novel gene responsible for lincosamide and streptogramin A resistance in Staphylococcus sciuri. Antimicrobial Agents and Chemotherapy 58(6):3335-3341.

Ibrahem MD (2015). Evolution of probiotics in aquatic world: potential effects, the current status in Egypt and recent prospective. Journal of Advance Research http://dx.doi.org/10. 1016/j.jare.2013.12.004.

Ibrahem MD, Mesalhy S (2010). Determining the safety and suitability of fluorescein 281 dye for characterization of skin ulcerations in cultured Nile tilapia (Oreochromis niloticus) and African sharptooth catfish (Clarias gariepinus). Journal of Advance Research 1:361-366.

Ige BA (2013). Probiotics use in intensive fish farming. International Journal of Agricultural Research and Natural Resources 1(1):001011.

Ishida Y, Ahmed AM, Mahfouz NB, Kimura T, El-Khodery SA, Moawad AA, Shimamoto T (2010). Molecular analysis of antimicrobial resistance in Gram-negative bacteria isolated from fish farms in Egypt. Journal of Veterinary Medical Sciences 72:727-734.

Jacobs L, Chenia HY (2007). Characterization of integrons and tetracycline resistance determinants in Aeromonas spp. isolated from South African aquaculture systems. International Journal of Food Microbiology 114:295-306. 
16

Janda JM, Abbott SL (2010). The genus Aeromonas: taxonomy, pathogenicity and infection. Clinical Microbiological Reviews 23(1):35-73.

Jiang HX, Tang D, Liu YH, Zhang XH, Zeng ZL, Xu L, Hawkey PM (2012). Prevalence and characteristics of $\beta$-lactamase and plasmid-mediated quinolone resistance genes in Escherichia coli isolated from farmed fish in China. Journal of Antimicrobial Chemotherapy 67:2350-2353.

Jiang RHY, de Bruijn I, Haas BJ, Belmonte R, Lobach L, Christie J, van den Ackerveken, Bottin A, Bulone V, Diaz-Moreno SM, Dumas B, Fan L, Gaulin E, et al. (2013). Distinctive expansion of potential virulence genes in the genome of the oomycete fish pathogen Saprolegnia parasitica. PLoS Genetics 9(6):e1003272. doi:10.1371/journal.pgen.1003272.

Johnson AP, Woodford N (2012). Global spread of antibiotic resistance: the example of New Delhi metallo-beta-lactamase (NDM)-mediated carbapenem resistance. Journal of Medical Microbiology 62:499-513.

Jones JG, Gardener S, Simon BM, Pickup RW (1986). Factors affecting the measurement of antibiotic resistance in bacteria isolated from lake water. Journal of Applied Microbiology 60(5):455-462.

Jun LJ, Jeong JB, Huh MD, Chung JK, Choi DL, Lee CH, Jeong HD (2004). Detection of tetracycline-resistance determinants by multiplex polymerase chain reaction in Edwardsiella tarda isolated from fish farms in Korea. Aquaculture 240:89-100.

Kataja J, Huovinen P, Seppala H (2000). Erythromycin resistance genes in group A streptococci of different geographical origins: the macrolide resistance study group. Journal of Antimicrobial Chemotherapy 46:789-792.

Khairnar K, Raut MP, Chandekar RH, Sanmukh SG, Paunikar WN (2013). Novel bacteriophage therapy for controlling metallo-betalactamase producing Pseudomonas aeruginosa infection in catfish. BMC Veterinary Research 9:264.

Khodursky AB, Cozzarelli NR (1998). The mechanism of inhibition of topoisomerase IV by quinolone antibacterials. Journal of Biological Chemistry 273:27668-27677.

Kleinkauf N, Hausemann A, Kempf VAJ, Gottschalk R, Heudorf U (2014) Burden of carbapenem-resistant organisms in the Frankfurt/Main Metropolitan Area in Germany 2012/2013 first results and experiences after the introduction of legally mandated reporting. BMC Microbiology 14:446.

Komar C, Enright WJ, Grisez L, Tan Z (2004). Understanding fish vaccination Tanhttp://www.thefishsite.com/focus/contents/understandding-fish-vaccination.pdf.

Krumperman PH (1983). Multiple antibiotic resistance indexing of Escherichia coli to indentify high risk sources of fecal contamination of foods. Applied and Environmental Microbiology 46:165-170.

Kruse H, Sørum H (1994). Transfer of multiple drug resistance plasmids between bacteria of diverse origins in natural microenvironments. Applied and Environmental Microbiology 60:4015-4021.
Kumar D, Prasad Y, Singh AK, Ansari A (2012). Columnaris disease and its drug resistance in cultured exotic African catfish Clarias gariepinus in India. Biochemical and Cellular Archives 12(2):415420.

Kummerer K (2009). Antibiotics in the aquatic environment - a review - part I. Chemosphere 75:417-434.

Kummerer K (2004). Resistance in the environment. Journal of Antmicrobial Chemotherapy 54: 311-320.

Laith AR, Najiah M (2013). Aeromonas hydrophila: antimicrobial susceptibility and histopathology of isolates from diseased catfish, Clarias gariepinus (Burchell). Journal of Aquaculture Research and Development 5:2215. doi:10.4172/2155-9546.1000215.

Laxminarayan R, Duse A, Wattal A, Zaidi AKM, Wertheim HFL, Sumpradit N, Vlieghe E, Hara GL, Gould IM, Goossens H, Greko C, So AD, Bigdeli M, Tomson G, Woodhouse W, Ombaka E, Peralta AQ, Qamar FN, Mir F, Kariuki S, Bhutta ZA, Coates A, Bergstrom R, Wright GD, Brown ED, Cars O (2013). Antibiotic resistance - the need for global solution. The Lancet http://dx.doi.org/10.1016/S1473-3099(13)70318-9.

Lebreton F, Depardieu F, Bourdon N, Fines-Guyon M, Berger P, Camiade S, Leclercq L, Courvalin P, Cattoir V (2011). DAla-D-Ser VanN-type transferable vancomycin resistance in Enterococcus faecium. Antimicrobial Agents and Chemotherapy 55(10):4606-4612.

Leclercq R (2002). Mechanisms of resistance to macrolides and lincosamides: nature of the resistance elements and their clinical implications. Clinical and Infectious Diseases 34:482-492.

Li XZ (2005). Quinolone resistance in bacteria: emphasis on plasmidmediated mechanisms. International Journal of Antimicrobial Agents 25:453-463.

Little DC, Edwards P (1999). Alternative strategies for livestock-fish integration with emphasis on Asia. Ambio 28:118-124.

Livermore DM (2003). Bacterial resistance: origins, epidemiology, and impact. Clinical and Infectious Diseases 36(Suppl 1):S11S23.

Livermore DM, Brown DF (2001). Detection of beta-lactamase mediated resistance. Journal of Antimicrobial Chemotherapy 48:59-64.

Livermore DM, Woodford N (2006). The beta-lactamase threat in Enterobacteriaceae, Pseudomonas and Acinetobacter. Trends in Microbiology 14:413-420.

Lopez P, Espinosa M, Greenberg B, Lacks S (1987). Sulfonamide resistance in Streptococcuspneumoniae: DNA sequence of the gene encoding dihydropteroate synthase and characterization of the enzyme. Journal of Bacteriology 169(9):4320-4326.

Matsuoka M, Endou K, Kobayashi H, Inoue M, Nakajima Y (1998). A plasmid that encodes three genes for resistance to macrolide antibiotics in Staphylococcus aureus. FEMS Microbiology Letters 167:221-227.

McCalla DR, Olive P, Tu Y, Fan ML (1975). Nitrofurazone-reducing enzymes in $E$. coli and their role in drug activation in vivo. Canadian Journal of Microbiology 21:1484-1491.

McCalla DR, Reuvers A, Kaiser C (1970). Mode of action of nitrofurazone. Journal of Bacteriology 104:1126-1134. 
McGee L, Klugman KP, Wasas A, Capper T, Brink A (2001). Serotype 19f multiresistant pneumococcal clone harboring two erythromycin resistance determinants $(\operatorname{erm}[\mathrm{B}]$ and $m e f[\mathrm{~A}])$ in South Africa. Antimicrobial Agents and Chemotherapy 45:15951598.

McManus MC (1997). Mechanisms of bacterial resistance to antimicrobial agents. American Journal of Health-System Pharmacy 54:1420-1433.

Méndez-Álvarez S, Pérez-Hernández X, Claverie-Martín F (2000). Glycopeptide resistance in enterococci. International Microbiology 3:71-80.

Mesa RJ, Blanc V, Blanch AR, Cortes P, Gonzalez JJ, Lavilla S, Miro E, Muniesa M, Saco M, Tortola MT, Mirelis B, Coll P, Llagostera M, Prats G, Navarro F (2006). Extended-spectrum $\beta$-lactamaseproducing Enterobacteriaceae in different environments (humans, food, animal farms and sewage). Journal of Antimicrobial Chemotherapy 58:211-215.

Miranda CD, Tello A, Keen PL (2013). Mechanisms of antimicrobial resistance in finfish aquaculture environments. Frontiers in Microbiology 4:233.

Miranda CD, Zemelman R (2002). Bacterial resistance to oxytetracycline in Chilean salmon farming. Aquaculture 212:3147.

Moellering RC Jr, Krogstad DJ (1979). Antibiotic resistance in enterococci. In: Schlessinger D (Ed). Microbiology. Washington, DC: Am Soc Microbiol pp 293-298.

Morris D, Rook K, Shofer F, Rankin S (2006). Screening of Staphylococcus aureus, Staphylococcus intermedius, Staphylococcus schleiferi isolates obtained from small companion animals for antimicrobial resistance: A retrospective review of 749 isolates (2003-04). Veterinary Dermatology 17:332-337.

Morrison BJ, Rubin JE (2015). Carbapenemase producing bacteria in the food supply escaping detection. PLoS ONE doi:10.1371/journal.pone.0126717.

Murray IA, Shaw WV (1997). O-acetyltransferases for chloramphenicol and other natural products. Antimicrobial Agents and Chemotherapy 41:1-6.

Musa N, Wei LS, Wee W, Musa N (2009). Bacterial diseases outbreak of African Catfish (Clarias gariepinus) from Manir River, Terengganu, Malaysia. Journal of Life Science 3(5):10-20.

Musefiu TA, Obuko EB, Bolarinwa AO (2011). Isolation and identification of aerobic bacteria flora of the skin and stomach of wild and cultured Clarias gariepinus and Oreochromis niloticus from Ibadan, Southwest, Nigeria. Journal of Applied Sciences Research 7:1047-1051.

Musefiu TA, Olasunkanmi SM (2015). Antibiotics resistance in bacteria strains isolated from fish: potential health risk. Journal of Biology, Agriculture and Healthcare, 10(5):www.iiste.org.

Muziasari WI, Managaki S, Parnanen K, Karkman A, Lyra C, Tamminen M , Suzuki S, Virta M (2014). Sulphonamide and trimethoprim resistance genes persist in sediments at Baltic sea aquaculture farms but are not detected in the surrounding environment. PLoS ONE 9(3): e92702.
Nahiduzzaman M, Ehshan MA, Chowdhury BR, Mridha MAR (2000). Studies on bacterial flora in a farmed catfish, Clarias hybrid. Pakistan Journal of Biological Science 3(3):429-432.

Nawaz M, Khan AA, Khan S, Sung K, Kerdahi K, Steele R (2009). Molecular characterization of tetracycline-resistant genes and integrons from avirulent strains of Escherichia coli isolated from catfish. Foodborne Pathogens and Diseases 6:553-559.

Ndi OL, Barton MD (2012). Resistance Determinants of Pseudomonas species from aquaculture in Australia. Journal of Aquaculture Research and Development 3:119. doi:10.4172/2155-9546.1000119.

Ndi OL, Barton MD (2011). Incidence of class 1 integron and other antibiotic resistance determinants in Aeromonas spp. from rainbow trout farms in Australia. Journal of Fish Diseases 34(8):589-599.

Ng KH, Samuel L, Kathleen MM, Leong SS, Felecia C (2014). Distribution and prevalence of chloramphenicol-resistance gene in Escherichia coli isolated from aquaculture and other environment. International Food Research Journal 21(4):13211325.

Nikiema J, Figoli A, Weissenbacher N, Langergraber G, Marrot B, Moulin P (2013). Waste water treatment practices in Africa experiences from seven countries. Sustainable Sanitation Practices 14:27-34.

Normark BH, Normark S (2002). Evolution and spread of antibiotic resistance. Journal of Internal Medicine 252:91-106.

Ogunshe AAO, Olabode OP (2009). Antimicrobial potentials of indigenous Lactobacillus strains on Gram-negative indicator bacterial species from Clarias gariepinus (Burchell.) microbial inhibition of fish-borne pathogens. African Journal of Microbiology Research 3(12):870-876.

Okeke IN, Edelman R (2001). Dissemination of antibiotic-resistant bacteria across geographic borders. Clinical and Infectious Diseases 33:364-369.

Okoh AI, Etinosa O, Igbinosa EO (2010). Antibiotic susceptibility profiles of some Vibrio strains isolated from wastewater final effluents in a rural community of the eastern Cape province of South Africa. BMC Microbiology 10:143.

Olatoye IO, Basiru A (2013). Antibiotic usage and oxytetracycline residue in African catfish (Clarias gariepinus) in Ibadan, Nigeria. World Journal of Fish and Marine Sciences 5:302-309.

Olayinka AO, Afolabi OO (2013). Evaluation of the effects of Lactobacillus acidophilus on the haematological parameters of Clarias gariepinus. International Journal of Research in Fisheries and Aquaculture 3(2):38-41.

Omojowo FS, Omojasola FP (2013). Antibiotic resistance pattern of bacterial pathogens isolated from cow dung used to fertilize Nigerian fish ponds. Notulae Scientia Biologicae 5(1):15-19.

Partridge SR, Tsafnat G, Coiera E, Iredell JR (2009). Gene cassettes and cassette arrays in mobile resistance integrons. FEMS Microbiological Reviews 33:757-784.

Paterson DL, Bonomo RA (2005). Extended-spectrum $\beta$-lactamases: a clinical update. Clinical Microbiology Reviews 18(4):657-686. 
Paulsen IT, Brown M, Skurray R (1996). Proton-dependent multidrug efflux systems. Microbiological Reviews 60:575-608.

Pereira J, Campos J, Mourao J, Barros M, Novais C, Peixe L, Antunes $P$ (2013). Aquaculture rainbow trout are contaminated with multidrug-resistant Enterobacteriaceae species carrying clinicallyrelevant antibiotic resistance genes. $23^{\text {rd }}$ Europeaen Society of Clinical Microbiology and Infectious Diseases.

Petersen A, Andersen JS, Kaewmak, T, Somsiri T, Dalsgaard A (2002). Impact of integrated fish farming on antimicrobial resistance in a pond environment. Applied and Environmental Microbiology 68:6036-6042.

Petersen A, Dalsgaard A (2003). Antimicrobial resistance of intestinal Aeromonas spp. and Enterococcus spp. in fish cultured in integrated broiler-fish farms in Thailand. Aquaculture 219:71-82.

Petersen A, Dalsgaard A (2003). Species composition and antimicrobial resistance genes of Enterococcus spp., isolated from integrated and traditional fish farms in Thailand. Environmental Microbiology 5:395-402.

Peterson FJ, Mason RP, Hovsepian J, Holtzman JL (1979). Oxygensensitive and insensitive nitroreduction by Escherichia coli and rat hepatic microsomes. Journal of Biological Chemistry 254:40094014.

Piscitelli SC, Rodvold KA, Pai MP (2011). Drug interactions in infectious diseases [Internet]. Totowa, NJ: Humana Press doi:10.1007/978-1-61779-213-7.

Poirel L, Cattoir V, Nordmann P (2012). Plasmid-mediated quinolone resistance: interactions between human, animal, and environmental ecologies. Frontiers in Microbiology 3:24.

Poirel L, Cattoir V, Nordmann P (2008). Is plasmid-mediated quinolone resistance a clinically significant problem? Clinical Microbiology and Infection 14:295-297.

Poirel L, Walsh TR, Cuvillier V, Nordmann P (2011). Multiplex PCR for detection of acquired carbapenemase genes. Diagnostic Microbiology and Infectious Diseases 70:119-123.

Reda RM, Ibrahim RE, Ahmed EG, El-Bouhy ZM (2013). Effect of oxytetracycline and florfenicol as growth promoters on the health status of cultured Oreochromis niloticus. Egyptian Journal of Aquatic Research 39:241-248.

Rhodes G, Huys G, Swings J, McGann P, Hiney M, Smith P, Pick RW (2000). Distribution of oxytetracycline resistance plasmids between aeromonads in hospital and aquaculture environments: implication of Tn1721 in dissemination of the tetracycline resistance determinant tetA. Applied and Environmental Microbiology 66:3883-3890.

Richards RM, Taylor RB, Zhu ZY (1996). Mechanism for synergism between sulphonamides and trimethoprim clarified Journal of Pharmacy and Pharmacology 48(9):981-984.

Roberts MC (1996). Tetracycline resistance determinants: mechanisms of action, regulation of expression, genetic mobility, and distribution. FEMS Microbiology Reviews 19:1-24.

Roberts MC (2003). Tetracycline therapy: update. Clinical and Infectious Diseases 36(4):462-467.

Roberts MC (2005). Update on acquired tetracycline resistance genes. FEMS Microbiology Letters 245:195-203.
Roberts MC, Schwarz S, Aarts HJM (2012). Erratum: acquired antibiotic resistance genes: an overview. Frontiers in Microbiology 3:384.

Roberts MC, Sutcliffe J, Courvalin P, Jensen LB, Rood J, Seppala H (1999). Nomenclature for macrolide and macrolide-lincosamidestreptogramin B resistance determinants. Antimicrobial Agents and Chemotherapy 43:2823-2830.

Rodgers CJ, Furones MD (2009). Antimicrobial agents in aquaculture: practice, needs and issues. In: Rogers C, Basurco B (Ed). The use of veterinary drugs and vaccines in Mediterranean aquaculture. Zaragoza: CIHEAM pp 41-59.

Rodkhum C, Maki T, Hirono I, Aoki T (2008). gyrA and parC associated with quinolone resistance in Vibrio anguillarum. Journal of Fish Diseases 31:395-399.

Romero J, Feijoo CJ, Navarette P (2011). Antibiotics in aquaculture: use, abuse and alternatives. In: Carvalho ED, David GS, Silva RJ (Eds). Health and Environment in Aquaculture. http://www.intechopen.com.

Ross JI, Eady EA, Cove JH, Cunliffe WJ, Baumberg S, Wootton JC (1990). Inducible erythromycin resistance in staphylococci is encoded by a member of the ATP-binding transport super-gene family. Molecular Microbiology 4:1207-1214.

Ruiz J (2003). Mechanisms of resistance to quinolones: target alterations, decreased accumulation and DNA gyrase protection. Journal of Antimicrobial Chemotherapy 51:1109-1117.

Ryu SH, Park SG, Choi SM, Hwang YO, Ham HJ, Kim SU, Lee YK, Kim MS, Park GY, Kim KS, Chae YZ. (2012). Antimicrobial resistance and resistance genes in Escherichia coli strains isolated from commercial fish and seafood. International Journal of Food Microbiology 152(1-2):14-18.

Sandegren L, Lindqvist A, Kahlmeter G, Andersson DI (2008). Nitrofurantoin resistance mechanism and fitness cost in Escherichia coli. Journal of Antimicrobial Chemotherapy 62:495503.

Sayah RS, John BK, Yvette J, Rose AM (2005). Patterns of antimicrobial resistance observed in Escherichia coli isolates obtained from domestic-and wild-animal fecal samples, human septage, and surface water. Applied and Environmental Microbiology 71:1394-1404.

Schamburg F, Köck R, Mellmann A, Köksal M, Jurke A, Becker K, Freidrich W (2013). Livestock-associated methicillin-resistant Staphylococcus aureus (MRSA) as causes of human infection and colonization in Germany. PLoS ONE 8(2):e55040.

Schlunzen F, Zarivach R, Harms J, Bashan A, Tocilj A, Albrecht R, Yonath A, Franceschi F (2001). Structural basis for the interaction of antibiotics with the peptidyl transferase centre in eubacteria. Nature 413:814-821.

Schmidt AS, Bruun MS, Dalsgaard I, Larsen JL (2001). Incidence, distribution and spread of tetracycline resistance determinants and integron-associated antibiotic resistance genes among motile aeromonads from a fish-farming environment. Applied and Environmental Microbiology 67:5675-5682.

Schwarz S, Chaslus-Dancla E (2001). Use of antimicrobials in veterinary medicine and mechanisms of resistance. Veterinary Research 32:201-225. 
Schwarz S, Kehrenberg C, Doublet B, Cloeckaert A (2004). Molecular basis of bacterial resistance to chloramphenicol and florfenicol. FEMS Microbiology Reviews 28:519-542.

Sergelidis D, Abrahim A, Papadopoulos T, Soultos N, Martziou E, Koulourida V, Govaris A, Pexara A, Zdragas A, Papa A (2014). Isolation of methicillin-resistant Staphylococcus spp. from ready-toeat fish product. Letters in Applied Microbiology 59:500-506.

Serrano PH (2005) Responsible use of antibiotics in aquaculture. FAO Fisheries technical paper 469.

Shah SQ, Colquhoun DJ, Nikuli HL, Sørum H (2012). Prevalence of antibiotic resistance genes in the bacterial flora of integrated fish farming environments of Pakistan and Tanzania. Environmental Science Technology 6(16):8672-8679.

Shaw WV (1983). Chloramphenicol acetyltransferase, enzymology and molecular biology. Critical Reviews in Biochemistry and Molecular Biology 14:1-46.

Shaw WV, Leslie AG (1991). Chloramphenicol acetyltransferase. Annual Review in Biophysics and Biophysical Chemistry 20:363386.

ShobrakMY, Abo-Amer AE (2014). Role of wild birds as carriers of multi-drug resistantEscherichia coli and Escherichia vulneris. Brazilian Journal of Microbiology 45(4):1199-1209.

Si H, Zhang W-J, Chu S, Wang X-M, Dai L, Hua X, Dong Z, Schwarz S, Liu S (2015). Novel Plasmid-borne multidrug resistance gene cluster including $l s a(\mathrm{E})$ from a linezolid-resistant Enterococcus faecium isolate of swine origin. Antimicrobial Agents and Chemotherapy 59(11):7113-7116.

Sihag RC, Sharma P (2012). Probiotics: the new ecofriendly alternative measures of disease control for sustainable aquaculture. Journal of Fisheries and Aquatic Science 7(2):72-103.

Smith P (2008). Antimicrobial resistance in aquaculture. Revue scientifique et technique (International Office of Epizootics) 27(1):243-264.

Sofia HJ, Chen G, Hetzler BG, Reyes-Spindola JF, Miller NE (2001). Radical SAM, a novel protein superfamily linking unresolved steps in familiar biosynthetic pathways with radical mechanisms: functional characterization using new analysis and information visualization methods. Nucleic Acids Research 29:1097-1106.

Soliman MK, Ellakany HF, Gaafar AY, Elbialy AK, Zaki MS, Younes AM (2011). Epidemiology and antimicrobial activity of methicillin-resistant Staphylococcus aureus (MRSA) isolated from Nile tilapia (Oreochromis niloticus) during an outbreak in Egypt. Life Sciences 11(10): http://www.lifesciencesite.com.

Sørum H, L'Abee-Lund TM, Solberg A, Wold A (2003). Integroncontaining IncU plasmids pRAS1 and pAr-32 from the fish pathogen Aeromonas salmonicida. Antimicrobial Agents and Chemotherapy 47:1285-1290.

Speer BS, Salyers AA (1989). Novel aerobic tetracycline resistance gene that chemically modifies tetracycline. Journal of Bacteriology 171:148-153.

Speer BS, Shoemaker NB, Salyers A (1992). Bacterial resistance to tetracycline: mechanisms, transfer, and clinical significance. Clinical Microbiology Reviews 5:387-399.

Su H-C, Ying G-G, Tao R, Zhang, R-Q, Fogarty LR, Kolpin DW (2011). Occurrence of antibiotic resistance and characterization of resistance genes and integrons in Enterobacteriaceae isolated from integrated fish farms in South China. Journal of Environmental Monitoring 13:3229-3332.

Sujatha S, Praharaj I (2012). Glycopeptide resistance in Gram-positive cocci: a review. Interdisciplinary Perspective on Infectious Diseases http://dx.doi.org/10.1155/2012/781679.

Suzuki S, Ogol M, Miller TW, Shimizu A, Takada H, Siringan MAT (2013). Who possesses drug resistance genes in the aquatic environment?: sulfamethoxazole (SMX) resistance genes among the bacterial community in water environment of Metro-Manila, Philippines. Frontiers in Microbiology 4:102.

Szczepanowski R, Linke B, Krahn I, Gartemann K-H, Gu tzkow T, Eichler W, Puhler A, Schluter A (2009). Detection of 140 clinically relevant antibiotic resistance genes in the plasmid metagenome of wastewater treatment plant bacteria showing reduced susceptibility to selected antibiotics. Microbiology 155:2306-2319.

Tait-Kamradt A, Clancy J, Cronan M, Dib-Hajj F, Wondrack L, Yuan W, Sutcliffe J (1997). mefE is necessary for the erythromycin-resistant M phenotype in Streptococcus pneumoniae. Antimicrobial Agents and Chemotherapy 41:2251-2255.

Tait-Kamradt A, Davies T, Appelbaum PC, Depardieu F, Courvalin P, Petitpas J, Wondrack L, Walker A, Jacobs MR, Sutcliffe J (2000). Two new mechanisms of macrolide resistance in clinical strains of Streptococcus pneumoniae from Eastern Europe and North America. Antimicrobial Agents and Chemotherapy 44:3395-3401.

Tajbakhsh E, Khamesipour F, Ranjbar R, Ugwu IC (2015). Prevalence of class 1 and 2 integrons in multi-drug resistant Escherichia coli isolated from aquaculture water in Chaharmahal Va Bakhtiari province, Iran. Annals of Clinical Microbiology and Antimicrobials 14:37.

Tamminen M, Karkman A, Lo`hmus A, Muziasari WI, Takasu H, Wada S, Suzuki S, Virta M (2011). Tetracycline resistance genes persist at aquaculture farms in the absence of selection pressure. Environmental Science and Technology 45:386-391.

Tauch A, Zheng Z, Puhler A, Kalinowski J (1998). Corynebacterium striatum chloramphenicol resistance transposon Tn5564, genetic organization and transposition in Corynebacterium glutamicum. Plasmid 40:126-139.

Taylor DE, Chau A (1996). Tetracycline resistance mediated by ribosomal protection. Antimicrobial Agents and Chemotherapy $40: 1-5$.

Tenover FC (2006). Mechanisms of antimicrobial resistance in bacteria. The American Journal of Medicine 119(6):3-10.

Tenson T,Lovmar M, Ehrenberg M. (2003). The mechanism of action of macrolides, lincosamides and streptogramin B reveals the nascent peptide exit path in the ribosome. Journal of Molecular Biology 330(5):1005-1014.

Then RL (1982). Mechanisms of resistance to trimethoprim, the sulfonamides, and trimethoprim-sulfamethoxazole. Reviews of Infectious Diseases 4:261-269.

Tirado MC, Clarke R, Jaykus LA, McQuatters-Gollop A, Frank JM (2010). Climate change and food safety: a review. Food Research International 43:1745-1765. 
20

Torimiro N, Bebe PT, Ogundipe FE, Esan DM, Aduwo AI (2014). The bacteriology and physico-chemical analysis of freshwater fish ponds International Research Journal of Microbiology 5(3):2832.

Tran JH, Jacoby GA (2002). Mechanism of plasmid-mediated quinolone resistance. Proceedings of National Academy of Science U.S.A. 99:5638-5642.

Urmunova V (2015). Extended spectrum beta-lactamase producing animal enterobacteriaceae isolates as potential risk to public health. Revue de Medicine Veterinaire 166:7-8:192-207.

United States Food and Drug Agency (USFDA) (2009). Approved drugs in aquaculture. http//:wwww.ApprovalProcess/Aquaculture/ucm 132954.htm.

Van TT, Chin J, Chapman T, Tran LT, Coloe PJ (2008). Safety of raw meat and shellfish in Vietnam: an analysis of Escherichia coli isolations for antibiotic resistance and virulence genes. International Journal of Food Microbiology 124(3):217-223.

Vass M, Hruska K, Franek M (2008). Nitrofuran antibiotics: a review on the application, prohibition and residual analysis. Veterinarni Medicina 53(9):469-500.

Vaz-Moreira I, Nunes OC, Manaia CM (2014). Bacterial diversity and antibiotic resistance in water habitats: searching the links with the human microbiome. FEMS Microbiology Reviews doi: 10.1111/1574-6976.12062.

Verner-Jeffreys DW, Welch TJ, Schwarz T, Pond MJ, Woodward MJ, Haig SJ, Rimmer GSE, Roberts E, Morrison V, Baker-Austin C (2009). High prevalence of multidrug-tolerant bacteria and associated antimicrobial resistance genes isolated from ornamental fish and their carriage water. PLoS ONE 4(12): e8388.

Vinod MG, Shivu MM, Umesha KR, Rajeeva BC, Krohne G, Karunasagar I, Karunasagar I (2006). Isolation of Vibrio harveyi bacteriophage with a potential for biocontrol of luminous vibriosis in hatchery environments. Aquaculture 255:117-124.

Waters AE, Contente-Cuomo T, Buchhagen J, Liu CM, Watson L, Pearce K, Foster JT, Bowers J, Driebe EM, Engelthaler DM, Keim PS, Price LB (2011). Multidrug resistant Staphylococcus aureus in US meat and poultry. Clinical and Infectious Diseases 52:1-4.

Weese JS, Van Duijkeren E (2010). Methicillin-resistant Staphylococcus aureus and Staphylococcus pseudintermedius in veterinary medicine. Veterinary Microbiology 140:418-429.

Wegener HC, Aarestrup FM, Jensen LB, Hammerum AM, Bager F (1999). Use of antimicrobial growth promoters in food animals and Enterococcus faecium resistance to therapeutic antimicrobial drugs in Europe. Emerging and Infectious Diseases 5:329-335.
Wei LS, Musa N, Seng CT, Mohd NA, Wee SW, Musa N, Wahid MEA (2011). Antibiogram and plasmid profiling from Edwardsiella tarda isolated from freshwater fish in East coast Malaysia. Journal of Sustainable Science and Management 6(1):19-27.

Weisblum B (1995). Erythromycin resistance by ribosome modification. Antimicrobial Agents and Chemotherapy 39:577585.

Werner G, Coque TM, CMAP Franz, Grohmannd E, Hegstade K, Jenseng L, van Schaikh W, Weaveri K (2013). Antibiotic resistant enterococci - tales of a drug resistance gene trafficker. International Journal of Medical Microbiology 303(6-7):360-79.

Weston DP (1996). Environmental considerations in the use of antibacterial drugs in aquaculture. In: Baird DJ, Beveridge MCM, Kelly LA, Muir JF (Eds). Aquaculture and Water Resource Management. Blackwell Science, Oxford p 140.

Whiteway J, Koziarz P, Veall J, Sandhu N, Kumar P, Hoecher B, Lambert IB (1998). Oxygen-insensitive nitroreductases: analysis of the roles of nfsA and $\mathrm{nfs} B$ in development of resistance to 5nitrofuran derivatives in Escherichia coli. Journal of Bacteriology 180:5529-5539.

World Health Organization (WHO) (2006). Guidelines for a safe use of wastewater and excreta in agriculture and aquaculture (2nd edition). World Health Organisation, Geneva, Switzerland.

World Health Organization (WHO) (2014). Antimicrobial resistance: global report on surveillance. World Health Organization.

Wilke MS, Lovering AL, Strynadka NCJ (2005). Beta-lactam antibiotic resistance: a current structural perspective. Current Opinion in Microbiology 8:525-533.

Wulf M, Voss A (2008). MRSA in livestock animals - an epidemic waiting to happen? Clinical Microbiology and Infection 14:519521.

Yim G, Thaker MN, Koteva K, Wright G (2014). Glycopeptide antibiotic biosynthesis. Journal of Antibiotics 67:31-41.

Zurek L, Ghosh A (2014). Insects represent a link between food animal farms and the urban environment for antibiotic resistance traits. Applied and Environmental Microbiology 80(12):35623567.

Zurfluh K, Hächler H, Nüesch-Inderbinen M, Stephan R (2013). Characteristics of extended-spectrum $\beta$-lactamase- and carbapenemase-producing enterobacteriaceae isolates from rivers and lakes in Switzerland. Applied and Environmental Microbiology 79(9):3021-3026. 